\title{
Edirne Üç Şerefeli Camii’nin Sıva Üzerine Kalemişi Süslemeleri
}

Zekiye UYSAL *

$\ddot{O} z$

1437- 1447 yılları arasında Sultan II. Murat tarafından inşa ettirilmiştir. Cami’nin mimarı hakkında kesin bilgiler yoktur. Kitabelerde usta adı görülmemektedir. Bununla birlikte çeşitli yayınlarda mimar Muslihiddin ismi geçmektedir. Üç Şerefeli Cami, enine dikdörtgen harimde ikisi serbest altı ayağa oturan büyük merkezi kubbesi, bunun iki yanında ikişer küçük kubbe, anıtsal revaklı, şadırvanlı avlusu ve dört minaresiyle Osmanlı mimarisinde bir dönüm noktasıdır. Yapıda kalemişi bezemeler yoğun olmakla birlikte çini, renkli taş işçiliği ve mermer işçiliği de dikkati çeker. Bu çalışmada yapıdaki kalemişi süslemeler değerlendirilmiştir. Yapının kalemişi süslemeleri avlu revaklarının kubbelerinde, son cemaat yeri kubbelerinde ve harimdeki kubbelerde, kubbeye geçiş elemanlarının üzerinde yoğun bir biçimde uygulanmıştır. Ayrıca harimin kıble duvarında mihrap çevresinde ve altıgen baldakenin kemerleri üzerinde kalemişi süslemeler görülmektedir. Edirne Üç Şerefeli Cami’nin kalemişi süslemelerinin bir kısmı devrinin ana kompozisyonunu korumaktadır. Geçirdiği onarımlardan dolayı aralara barok, rokoko tarzı süslemeler karışmıştır.

Üç Şerefeli Cami, Edirne’ye büyük zarar veren 1752 depreminde hasar görmüştür. Bu sırada minarelerin belli bir seviyeye kadar yıkıldığı, bazı kubbelerin çöktüğü bilinmektedir. Yapı ilk olarak 1763 yılında onarım geçirmiştir. Daha sonra 1893- 1895 yılların da da onarım görmüştür. Cumhuriyet döneminde ise 1930-1960'lı yıllardaki onarımların ardından 1991 yılında tekrar onarıma alınmış ve onarım çalışmaları 2019 yılında tamamlanmıştır. Bu çalışmalar sırasında barok süsleme büyük oranda kaldırılıp alttaki motif ve kompozisyonun üzerinden geçilerek yenilenmiştir. Aynı zamanda renklerin üzerinden de geçildiği için motifler yüzeyden kabarık bir hale gelmiştir.

Anahtar Kelimeler: Edirne, Osmanlı dönemi, Üç Şerefeli Camii, Kalemişi süsleme, Jel Kodu: A30

\section{Edirne Üç Şerefeli Mosque's Painted Decorations}

\begin{abstract}
It was built by Sultan Murat II between the years 1437 and 1447. There is no exact information about the architect of the mosque. The name of the architect cannot be found in the inscriptions. However, the name of architect Muslihiddin is mentioned in various publications. Üç Şerefeli Mosque is a turning point in Ottoman architecture due to the large central dome with a transverse rectangular shape, two of which sit freely on six blocks in harim, two small domes, a monumental portico, a yard with a fountain and four minarets. While painted decorations are intensely used in the structure, tile, colored stonework, and marble craftsmanship also attract attention. In this study, painted decorations on the building were evaluated. The painted decorations of the building were applied intensely on the domes of the courtyard porticos, the domes of the last congregation place and the domes in the harim, and the transition elements to the dome. Besides, there are decorations on the qiblah wall of the harim around the mihrab and the arches of the hexagonal baldaquin. Some of the painted decorations of the Edirne Üç Şerefeli Mosque preserved the main composition of its period. Baroque and rococo-style
\end{abstract}

\footnotetext{
* Doç. Dr., Çanakkale Onsekiz Mart Üniversitesi, Fen-Edebiyat Fakültesi, Sanat tarihi Bölümü, 
decorations were mixed into them due to the repair processes they have undergone.

Üç Şerefeli Mosque was damaged in the earthquake of 1752, which caused great damage to Edirne. Meanwhile, it is known that the minarets collapsed to a certain degree and some domes collapsed. The building was first repaired in 1763. Later, it was repaired in 1893-1895. In the Republic period, following the repairs in the 1930-1960s, it was taken under maintenance once again in 1991 and the repair was completed in 2019. During these operations, the baroque decorations were removed substantially and they were renewed by passing over the motif and composition below. At the same time, since the colors are passed over, the motifs became more visible on the surface.

Keywords: Edirne, Ottoman Period, Üç Şerefeli Mosque, Painted decoration,

Jel Code: A30

\section{GİRIŞ}

Bizans döneminde Adrianopole adıyla bilinen Edirne 1361 yılında I. Murat tarafından fethedilmiştir ${ }^{2}$. Bundan sonraki yıllarda Osmanlıların başkenti haline gelen şehirde inşa edilen yapıların en önemlilerinden birisi Üç Şerefeli Cami’dir.

Osmanlı mimarisi ile ilgili yayın ve araştırmalarda en çok üzerinde durulan yapılardan birisi olan Üç Şerefeli Cami’nin mimarisini ele alan yayınların başında Ayverdi’nin kitabı gelir. ${ }^{3}$ Ayrıca Doğan Kuban, Muzaffer Erdoğan, Oktay Aslanapa, Semavi Eyice, Abdullah Kuran, Suut Kemal Yetkin, M. Baha Tanman, A. Osman Uysal, gibi araştırmacıların Osmanlı mimarisini ele alan kitap ve makalelerinde yapıya az ya da çok değinilmiştir. ${ }^{4}$ Süslemeleri için ise Yıldız Demiriz'in yayınlanmış tezi ve makaleleri önemlidir ${ }^{5}$ Yapı, lisansüstü çeşitli çalışmalara da konu olmuştur. ${ }^{6}$ Bu makalede Üç Şerefeli Cami’nin kalemişi

2-H. İnalcık, “Edirne’nin Fethi”, Edirne: Edirne’nin 600. Fetih Yıldönümü Armağan Kitabı, Ankara 1965, s.159.

3- E.H. Ayverdi, Osmanlı Mimarisinde Çelebi ve II. Sultan Murad Devri, C.II, İstanbul 1972, s.422-459.

4-Bkz.; D. Kuban, Osmanl Mimarisi,, Yem Yayınları, İstanbul 2007, s.143-148; D. Kuban, Sinan'ın Sanatı ve Selimiye Tarih Vakfı Yayınları, İstanbul 1997, s.48;M.Erdoğan, "Osmanlı Devrinde Yapılan İmar Çalışmaları”, Güney-Doğu Avrupa Araştırmaları Dergisi, 6-7, (1977-1978), İstanbul 1978, s.121-188; O.Aslanapa, "Edirne’de Türk Mimarisinin Gelişmesi”, Edirne: Edirne’nin 600. Fetih Yıldönümü Armağan Kitabı, Ankara 1965, s.225; S.Eyice, "Edirne”, Türkiye Diyanet Vakfi İslam Ansiklopedisi, C.10, İstanbul 1994, s.435; A. Kuran, Mimar Sinan, Hürriyet Vakfı Yayınları, İstanbul 1986, s. 12; G.Goodwin, Osmanlı Mimarlı̆̆ Tarihi, Çev. M.Günay, Kabalcı Yayınevi, İstanbul 2012, s.119-123; M.B. Tanman, "Edirne’de Erken Dönem Osmanlı Camileri ve Özellikle Üç Şerefeli Cami Hakkında”, Edirne: Serhattaki Payitaht, (Haz. Emin Nedret İşli -M. Sabri Koz), Yapı Kredi Yayınları, İstanbul 1998, s.325-352; A.O. Uysal, "Erken Osmanlı Mimarisinde Minareler”, Osmanlı, C.10, Yeni Türkiye Yayınları, Ankara 1999, s.149-160.

5-Y.Demiriz, bu yapıdaki kalem işlerine ilk önce Süheyl Ünver'in değindiğini belirtir. Bu konuda ve yapının süslemeleri hakkında bkz.; Y. Demiriz, Osmanlı Mimarisinde Süsleme, I, Erken Devir (1300-1453), Kültür Bakanlığı Yayınları, İstanbul 1979, s.513-540 ; Y. Demiriz, “Osmanlı Kalem İşleri”, Osmanlı, C.11, Ankara 1999, s.297-304

6- G. M. Altınsoy,Edirne Camilerinde18.Yüzyıl Onarımları, İstanbul Teknik Üniversitesi, Fen Bilimleri Enstitüsü, (Yayınlanmamış Doktora Tezi), İstanbul 1999; F. Köse Sayan, Erken Osmanlı Camileri İçinde Edirne Üç Şerefeli Cami ve Belgeler Üzerinden Cumhuriyet Dönemine Kadar Geçirdiği Onarımlar, Yıldız Teknik Üniversitesi, Fen Bilimleri Enstitüsü (Yayınlanmamış Yüksek Lisans Tezi) İstanbul 2018; A. F. Baysal, Edirne Osmanlı 
süslemelerinin ele alınarak tartışılması amaçlanmıştır. Araştırmamız, yapı üzerinde 2004 yılından itibaren 2019 yılına kadar sürdürdüğümüz yerinde incelemelere dayanmaktadır.

Şehrin merkezi dokusunda, (Res.1; Şek.1), Eski Cami'nin kuzeybatısında kalan yapı; Selimiye’nin inşasına kadar "Yeni Cami” adıyla biliniyordu. ${ }^{7}$ Üç Şerefeli Cami’nin kapıları üzerinde yer alan üç kitabeden çıkarılan bilgilere göre; 1437 - 1447 yılları arasında Sultan II. Murad tarafından inşa ettirilmiştir ${ }^{8}$ Evliya Çelebi’nin, yapının inşasına İsa ve Musa Çelebiler tarafından başlanıldığı yolundaki bilgileri hatalıdır. ${ }^{9}$ Bu hatalı görüşe 19. Yüzyıl kaynaklarından Bâdî Efendi tarafından da dikkat çekilmiştir. ${ }^{10}$

Caminin mimarı konusunda kesinleşmiş bilgiler yoktur. Kitabelerde usta adı geçmez. Buna karşılık Edirne'li Rûhi'nin Osmanlı Tarihinde, Sultan II. Murad'ın caminin inşası görevini Mimar Usta Muslihiddin'e verdiği ve Usta Şahabeddin’in de mimarın yanında çalıştığına dair bilgiler vardır. ${ }^{11}$ Diğer taraftan Beşir Çelebi Üç Şerefeli Cami’nin mimarının felçli bir mimar olduğunu belirtir; fakat isim vermez ${ }^{12}$. Bu iki kişi, aynı sanatçı olabilir.

Üç Şerefeli Cami, Edirne'ye çok zarar veren 1752 tarihli depremde hasar görmüştür. Bu sırada minarelerin belli bir seviyeye kadar yıkıldığı, bazı kubbelerin çöktüğü bilinmektedir. Yap1 1752 yılındaki ${ }^{13}$ depremden sonra 1763 'te onarılmıştır ${ }^{14}$.Son yapılan arşiv çalışmalarında yapının 1893 ve 1895 yıllarında da onarım gördüğü tespit edilmiştir. ${ }^{15}$ Söz konusu depremin ardından yapılan onarım ve 19. yüzyıl sonlarındaki onarımlar sırasında özellikle kubbeler ve eteklerindeki kalem işlerinin bir bölümünün üzeri dönemin Barok üslubunu yansıtan kalem işleriyle kaplanmıştır. Bu açıdan en çarpıcı uygulama harimde mihrapönü kubbesinde göze çarpar. Bu kubbenin yüzeyi bağdadî teknikte kaplanarak geç dönemin modasına uygun Barok kalemişleriyle kaplanmıştı. Ayverdi, bu kaplama ve

Erken Dönem Camileri Kalemişi Ornekleri ve Analizleri, Necmettin Erbakan Universitesi, Sosyal Bilimler Enstitüsü, (Yayınlanmamış Doktora Tezi) Konya 2013.

7-V.L. Menage, “Edirne’li Rûhi’ye Atfedilen Osmanlı Tarihinden İki Parça”, Ord. Prof. İsmail Hakkı Uzunçarşılı'ya Armă̆an, Türk Tarih Kurumu Yayınları, Ankara 1976, s. 329; M.T. Gökbilgin, "Edirne Hakkında Yazılmış Tarihler”, Edirne: Edirne’nin 600. Fetih Yıldönümü Armağan Kitabı, Ankara 1965, s.79.

8-Kitabe metinleri daha önce yayınlanmıştır. Bkz.; M.T.Gökbilgin, XV-XVI. Asırlarda Edirne ve Paşa Livası, Üçler Matbaası, İstanbul 1952, s.213-214; O.Onur, Edirne, Türk Tarihi Vesikalarından Kitabeler, Yenilik Basımevi, İstanbul 1972, s.111-117; E.H. Ayverdi , a.g.e., s.458-459.

9-Evliya Çelebi Seyahatnamesi, (Haz.S. A Kahraman-Yücel Dağlı), C.3, Yapı Kredi Yayınları, İstanbul 1999, s. 243 .

10-Ahmed Bâdî Efendi, Riyâz-I Belde-I Edirne (20. Yüzyıla Kadar Osmanlı Edirnesi), Trakya Üniversitesi Yayınları, İstanbul 2014, s.103.

11 - V.L. Menage, a.g.m., s.330.

12- Beşir Çelebi, Tarih-i Edirne: Hikayet-i Beşir Çelebi, (Haz: İ.H.Ertaylan),İstanbul Üniversitesi Edebiyat Fakültesi Yayınları,İstanbul 1960,s.5 . Mimar konusundaki farklı görüşler için bkz. ; O.Nuri Peremeci, Edirne Tarihi, Resimli Ay Matbaası, İstanbul 1939,s.56.

13- O.Nuri Peremeci, a.g.e., s.26.

14- E.H. Ayverdi, a.g.e., s.424.

15- F.K. Sayan,a.g.e.,111-115. 
bezemeleri kendisinin kaldırdığını nakleder. ${ }^{16}$ Cumhuriyet döneminde ise; 1930 ve 1960'lı yıllardaki onarımların ardından 1991 yılında üçüncü kez onarıma alınmıştır. Onarım çalışmaları 2019 yılında tamamlanmıştır. Bu çalışmalar sırasında barok süsleme büyük oranda kaldırılıp alttaki motif ve kompozisyonun üzerinden geçilerek yenilenmiştir. Aynı zamanda renklerin üzerinden de geçildiği için motifler yüzeyden kabarık bir hale gelmiştir.

Üç Şerefeli Cami, enine dikdörtgen harimde ikisi serbest altı ayağa oturan büyük merkezi kubbesi, bunun iki yanında ikişer küçük kubbe, anıtsal revaklı, şadırvanlı avlusu ve dört minaresiyle Osmanlı mimarisinde bir dönüm noktasıdır ${ }^{17}$. Osmanlı cami mimarlığında ilk defa bu yapıda anıtsal revaklı avluyla karşılaşılır. (Res.2)

Esas olarak kesme taş malzemeyle yığma duvar tekniği kullanılarak yapılan eserde tuğla kubbe geçişleri ve kubbelerde kullanılmıştır. Cephelerde pencerelerde ve batı taç kapısında, revak kemerlerinde ve minarelerde renkli taş almaşıklığı görülür.

Yapıda kalemişi bezemeler yoğun olmakla birlikte çini mozayik, renkli taş işçiliği ve mermer işçiliği de yer alır. Harimin batı kapısında ve kıble duvarındaki pencerelerin dış çerçevelerinde sınırlı ölçüde çini mozayik göze çarparken; çini süsleme, sadece avlunun kuzey duvarındaki pencerelerden ikisinin iç alınlığında dikkati çeker. Süheyl Ünver bunların üç tane olduğunu ifade etmektedir. ${ }^{18}$ Üçüncü çini panoya ne olduğu konusunda herhangi bir bilgi yoktur. Üç Şerefeli camide az miktarda çini kullanılmış olmasına rağmen portal, avlu kapıları, minareler, sütun başlıkları ve pencereler üzerinde dikkate değer taş işçiliği görülür. ${ }^{19}$ Ancak eserin asıl ve zengin süslemeleri sıva üzerine yapılan nakışlardır. Sıva üzerine yapılmış kalemişleri avlu revaklarının, son cemaat yerinin ve harimdeki kubbelerin ve kubbeye geçiş elemanlarının üzerinde yoğun bir biçimde uygulanmıştır. Ayrıca harimin kıble duvarında mihrap çevresinde ve altıgen baldakenin kemerleri üzerinde kalabilmiş süslemeler, yapının içerisinin rengârenk nakışlarla kaplandığını göstermektedir. (Res.3) 17. yüzyılda bu zengin süslemelerden övgüyle söz eden Evliya Çelebi, nakışların asırlardır bozulmadan kaldığını belirtir ${ }^{20}$. Fakat 18. yüzyılda meydana gelen deprem yapıyla birlikte süslemelere de zarar vermiştir. Bu depremin ardından gerçekleşen onarımdan sonra, yapı 19. yüzyılın sonlarında da onarılmıştır. ${ }^{21}$ Cumhuriyet döneminde yapılan onarımlarda sıva raspasının altından ortaya çıkan süslemelerin bir bölümü korunmuştur.

16- E.H. Ayverdi, a.g.e., s.423, 426, 434.

17- E.H. Ayverdi, a.g.e., s.422; S.K. Yetkin, Türk Mimarisi, Bilgi Yayınları, Ankara 1970, s.182.

18- S. Ünver, “Edirne Medeniyetimiz ve Tezyini Misalleri,", Edirne: Edirne’nin 600.Fetih Yıldönümü Armă̆an Kitabl, Ankara 1965, s. 246.

19- Y. Demiriz, Osmanlı Mimarisinde Süsleme, I, s.515

20- Evliya Çelebi Seyahatnamesi, a.g.e., s.243.

21- F. Köse Sayan, a.g.e., s.111. 


\section{KALEMISSí SÜSLEMELER}

Yapıdaki kalemişi süslemeler, revaklı avlunun doğu kapısının gerisindeki kubbeden itibaren kubbelere numara verilmek suretiyle sırayla ele alınmışlardır. Harimde ise mihrapönü kubbesinden başlamak üzere numaralar verilmiştir. Avludakiler "A" harimdekiler ise "H"şeklinde numaralandırılmışlardır. A 1 den A 7 ye kadar olan kubbelerin üzerine 1752 depreminde minare devrildiği için zarar gören kısımların yenilendiğini biliyoruz. ${ }^{22}$

KubbeNo.A.1: Avlunun güneydoğuköşesindekibu hacim, son cemaat yerinin doğu taraftan itibaren ilk ünitesi olup tümüyle onarım görmüştür. 1752 yılında yıkılan kısımlardan birisi olması gereken bu ünitenin başlangıçta çapraz tonozla örtülü olduğu kabul edilmektedir. ${ }^{23}$ 1763 yılındaki onarımda yenilenen tonozun biraz değişikliğe uğradığı görülmektedir. Bundan sonra yapıda 19.yüzyılda gerçekleşen onarımın daha çok örtü sistemindeki kalem işlerine yönelik olduğunu sanıyoruz. Camide gerçekleştirdiğimiz 2004 yılı incelemesi sırasında restorasyon iskelesi kurulu olduğu için göremediğimiz bezemeleri restorasyonu izleyen süreçte 2019 yılında inceleyebildik. Restorasyon sonrası görünümüne göre bu bölümün tonozu üzerindeki kalem işi süslemeleri şöyle tanımlayabiliriz: Yüzeye, kolları köşelerden başlayıp ortadaki dörtgen panoda biten dört kollu yıldız işlenerek; her biri dar ve uzun üçgeni andıran kolların içi bezenmiştir. Ortadaki dörtgen panonun içerisine ise geometrik geçmeli çokgen bir madalyon yerleştirilmiştir. Yıldızın kollarının içinde şemse formlu kartuşlar, rumi ve hatayili süslemeler göze çarpmaktadır. Kolların arasında dilimli çerçeveli bir şemse motifi görülür. Şemseyi çerçeveleyen iki şerit merkeze doğru yükselerek dügümlü geometrik kompozisyonla yıldızın iç köşesine bağlanır. Şemsenin alt ucu palmetle sonlanır. Şemsenin iki yanında yukarı doğru uzanan birer çiçek buketi yer alır. Bu şema dört kollu yıldızın aralarında nöbetleşe biçimde tekrar eder. Tonoz eteğini ise rumili palmetli kartuş dizisi dolaşır. (Res.4)

Kubbe No.A.2: Avlunun güneydoğu köşesindeki bu hacim, son cemaat yerinin doğu taraftan itibaren ikinci ünitesi olup onarım görmüştür. Ovalimsi kubbeye pandantifle geçilir. Ana şema ortada bir madalyon, dügüumlü örgü şeritleriyle birbirine bağlanan kartuşlarla meydana getirilmiştir. Kartuşlar şemse formlu kartuşlarla birleşerek yüzeyde sekiz kollu yıldız meydana getirirler. Yıldız kollarının uçları palmetle sonlanır. Süslemelerin etrafını iki şerit çerçeveler. Pandantiflerin üzerinde dört kollu geometrik geçmeli madalyonlar yer alır. Kubbe eteğinde iki sıra bordür görülür. İlkinde ucu palmetle biten kartuşlar ve aralarına geometrik düğüm motifi nöbetleşe biçimde yerleştirilerek oluşturulmuş ve içleri yeşil ve siyah renkli boya ile renklendirilmiştir. İkincisinde ise enine uzanan kartuşlar yer alır. Bu kartuşlar ilk bordürde yer alan kartuşların aralarına denk gelecek biçimde yerleştirilmişlerdir. Bu kartuşların içinde rumili, hatayili, palmetli süslemeler göze çarpar. Bu kubbede süslemeler tümüyle yenilenmiştir. (Res.5)

Kubbe No.A.3: Avlunun güneydoğu köşesindeki bu hacim, son cemaat yerinin doğu

22- M. B. Tanman, a.g.m., s.341.

23- E.H.Ayverdi, a.g.e.,s.423 
taraftan itibaren üçüncü ünitesidir. Ortada bir madalyon ve merkezden çevreye doğru 1şınsal altılı kartuş esasına dayanan bir şema ile kompozisyon oluşturulmuştur. Bu kartuşlar dilimli şemse biçimindedir. Kartuşların içerisinde rumili, palmetli hatayili süslemeler görülür. Kubbe eteğindeki bordürde oldukça basit zikzaklı bir süslemeye yer verilmiştir. Pandantifler üzerinde de geometrik geçmeli madalyonlar yer alır. Bu kubbede de pandantiflerin etrafında düğümlü ikili şerit bulunmaktadır. (Res.6)

Kubbe No. A.4: Avlunun güneydoğu köşesindeki bu hacim, son cemaat yerinin doğu taraftan itibaren dördüncü ünitesidir. Ortada bir madalyon merkezden çevreye doğru ışınsal sekizli kartuş şeklinde bir düzenlemesi vardır. Kartuşlar dilimli şemse şeklidedirler. Kartuşların içerisine rumili palmetli ve hatayili süslemeler yerleştirilmiştir. Kubbe eteğindeki bordürde de kartuşlar görülür. Bunların içerisinde palmet ve rumiden oluşan süsleme dışında ise, gri ve beyaz renk kullanarak fırça darbeleriyle doldurmuşlardır. Pandantiflere küçük madalyonlar yapılmıştır. Madalyonların çevresi sarı zemin üzerine gri beyaz fırça darbeleriyle düzenlenmiştir. Trompların arasındaki yuvarlak kemerlerin yüzeylerine basit sekiz kollu yıldız ve aralarda dört kollu yıldız şeması işlenmiştir. (Res.7)

Kubbe No.A.5: Avlunun güneydoğu köşesindeki bu hacim, son cemaat yerinin doğu taraftan itibaren beşinci ünitesidir. A 3 numaralı kubbenin düzenlemesi ile aynıdır. Renkleri ana kompozisyonu hatta pandantiflerdeki madalyonlar bile birbirinin aynısıdır. Bu tarz tazelenmiş olan kubbelerde bazı yerler yanlış yorumlanmış ve ortaya bambaşka motifler çıkmıştır. Her müdahale de süslemelerin orjinalliğini biraz daha kaybetmesine sebep olmuştur. (Res.8)

Kubbe No.A.6: Avlunun güneydoğu köşesindeki bu hacim, son cemaat yerinin doğu taraftan itibaren altıncı ünitesidir. A 2 kubbesiyle aynı şemadadır. (Res.9)

Kubbe No.A.7: Avlunun güneydoğu köşesindeki bu hacim, son cemaat yerinin doğu taraftan itibaren yedinci ünitesidir. İncelediğimiz tarihte üzeri plakalarla kaplı olduğu için göremediğimiz kubbe onarım görmüştür. Bu kubbe A 1 şemasına benzer. Sadece dört kolllu yıldız kaldırılmıştır. (Res.10)

Kubbe No.A.8: Avlunun batı kapısının arkasındaki kubbe tümüyle onarım geçirmiştir. 2004 yılındaki kompozisyondan daha farklı bir şema karşımıza çıkar. O zaman ortada bir madalyon etrafında rokoko karakterde süslemeler yer alıyordu ve zeminde büyük bir bölüm boş bırakılmıştı. Pandantifler arasındaki sıvalar dökülmüştü. Daha sonraki restorasyonlarda sıva raspası altından çıkan süslemelere benzer şekilde yenilenmişlerdir. Rokoko tarzında çiçek buketleri görülür. Bunlardan birisi dönem eki olarak korunmuştur. (Res.11)

Kubbe No.A.9: Kubbenin etek kısmında her kenarda bir kartuş olmak üzere toplam altı kartuş içinde bir satır kufi, bir satıh nesih yazı kuşakları bulunmaktadır. Kubbe içinde altılı kartuş şeklinde bir düzenleme vardır. Bu altı kartuşun her birinin ortasından düğümlü örgü şeritleriyle geçmeler meydana getirilerek altılı 1şınsal simetrik kartuşlu bir 
sistem elde edilmiştir. Kartuşların içerisinde bitkisel süsleme vardır ama bunlar belirgin değildir. Kartuşların bittiği yerler, tepede bir palmetle sonlandırılmıştır. Kubbe içi boş yer kalmamacasına kıvrık dal üzerinde rumili süsleme ile doldurulmuştur. Kubbeye geçiş kısımlarında rokoko tarzı süslemeler vardır. Bu süslemenin bir kısmı dönem eki olarak korunmuştur. Kubbede gördügümüz şema 15.yy. daki ahşap üzerine yapılan kalem işlerindeki motiflerle büyük benzerlik göstermektedir. (Res.12)

Kubbe No.A.10: Kubbe eteği kufi yazılarla çevrelenmiştir. Kubbe ortasındaki küçük yuvarlak madalyon içinde sülüs yazı görülmektedir. Işınsal simetrik kompozisyon bu kubbede sekizli esasa göre düzenlenmiştir. Dügümlü çift örgü şeritleriyle elde edilen kartuşlardan dördünün içinde yazı, diğerlerinin içinde rumili kıvrık dallarla bezeli kompozisyon meydana getirilmiştir. Hatayi motifi ise bozulmuş bir şekilde karşımıza çıkar. Önceki fotoğraflarda kubbeye geçiş bölümlerinde barok tarzı süslemeler görülürken bunlar kaldırılmış yerine madalyon şemasında süslemeler yapılmıştır. Bu madalyonların aralarına denk gelecek şekilde kısa kenarları geometrik geçmeli dikdörtgen şeklinde kartuşlar yerleştirilmiştir. (Res.13)

Kubbe No.A.11: Işınsal sekizli simetrik düzendeki kubbede ortada bir madalyon ve şemseler, bunların arasındaki kartuşlar göze çarpmaktadır. Birbirlerine ikiz şeritlerle bağlanmışlardır. Gerek orta madalyon gerekse şemselerin içleri rumilerle bezenmiștir. Dış bölümlerde zemin boş bırakılmıştır. Kubbe eteğinde palmet dizileri yer alır. (Res.14)

Kubbe No.A.12: Bu kubbede de 1şınsal sekizli simetrik esasa göre tertiplenmiş merkezi kompozisyon görülür. (Res.) Merkezi kompozisyondaki kartuş şeklindeki bölmeler düğümlü çift şeritlerle elde edilmiştir. Merkezde kufi ve nesihin birlikte kullanıldığı yazı kartuşlarında simetrik rumili süsleme vardır. Bu merkezi kompozisyonun hemen dişında girlandlı bir çerçeve bulunuşu bu kısmının da onarım gördügünü gösterir. Daha dışta kufi yazı kartuşlarından bir kuşak vardır. Yazı kuşağının dışında kalan alandaki süslemeler silinmiştir. Pandantiflerde yine barok tarzı süslemeler kaldırılmış yerine madalyonlu düzenlemeler yerleştirilmiş yine bazı kısımlar onarım eki olarak bırakılmıştır. (Res.15)

Kubbe No.A.13: Burada merkezi kompozisyon içinde kufi yazıları olan ortada bir madalyon, ışınsal altılı simetrik kartuşlu bölmeler ve bu bölmelerin arasında palmetlerden oluşmuştur. Zemin bölmeleri düğümlü şeritlerle sağlanmıştır. Kartuşlar rumili palmetler ile hatayili simetrik kompozisyonlarla doldurulmuştur. Kubbe eteğinde ise tı̆̆ şeklinde düzenlenmiş geniş bir bordür sonra kartuşlar içinde alternatifli olarak kufi ve sülüs yazılar yer alır. Pandantiflerde yer alan barok tarzı süsleme kaldırılmış, madalyonlar yerleştirilmiştir. Bazı kısımlar onarım eki olarak korunmuştur. (Res.16)

Kubbe No.A.14: Zemin bölümlenmesi kubbe 13’e benzemekle birlikte orta madalyonda yazı kuşağı bulunmamaktadır. Kartuşların içerisinde rumili simetrik dolgular yer alır. Kubbe eteğinde onarım gördügü anlaşılan kufi yazı kuşağı bulunur. Pandantiflerde geometrik geçmeli kartuşlar yer alır. Bazı kısımlar onarım eki olarak korunmuştur. (Res.17) 
Kubbe No.A.15: Buradaki esas kompozisyon madalyon şemasına göre değil, iri rumilerin çarkıfelek düzenine göre yerleştirilmiştir. Bu rumilerin içine yazı yerleştirilmiştir. Rumilerde yanlış yorumlanmış detaylar görülür. Pandantifler üzerindeki kartuşlarda vazodan çıkan çiçekler şeklinde düzenlemeler görülür. Onarım eki olarak bazı kısımlar korunmuştur. (Res.18)

Kubbe No.A.16: Kubbe 13' inkine benzeyen düzende yapılmıştır. Orta madalyonda yazı kuşağı görülür. Işınsal altılı simetrik kartuşlu ve palmetli zemin bölmeleri düğümlü şeritlerle düzenlenmiştir. Palmet formları Kubbe 13'ten farklıdır. Ayrıca burada hatayi yoktur. Örgülü süsleme devrine uygun bir süslemedir. Kubbe eteğinde yine tı̆̆ şeklinde düzenlenmiş bir bordür yer alır. Bordürün altında da yenilenmiş kufi yazı göze çarpmaktadır. Onarım eki olarak bazı kısımlar korunmuştur. (Res.19)

Kubbe No.A.17: Işınsal altılı simetrik düzendeki kubbede ortada bir madalyon ve şemseler, bunların arasındaki kartuşlar göze çarpmaktadır. Birbirlerine ikiz şeritlerle bağlanmışlardır. Gerek orta madalyon gerekse şemselerin içleri rumilerle bezenmiştir. Bu sistemdeki dikdörtgene yakın kartuşların içine yazı yerleştirilmiştir. Kubbe eteğinde kartuşlar içinde kufi ve nesih bileşimi yazılar, bunun altında palmet dizileri yer alır. Pandantiflerde örgülü kemerle pandantif arasındaki sahada rokoko tarzı süslemeler görülür. Onarım eki olarak korunmuştur. (Res.20)

Kubbe No.A.18: Buradaki kubbede 1şınsal altılı simetrik bir kompozisyon düzeni içerisine kartuşlar yerleştirilmiştir. Şema olarak kubbe 17’ye benzer bir tarzdadır. Ancak orta madalyonda örgülü yazı kuşağı vardır. Pandantiflerde örgülü kemerle pandantif arasındaki sahada rumili kıvrık dallar ve palmetler ve şemse biçimli kartuşlar, düğümlü geçmeler görülür. Bunların bir kısmı onarım eki olarak korunmuştur. (Res.21)

Kubbe No.A.19: Sekizli ışınsal simetrik ana kompozisyonda düğümlü ikiz şeritlerle şemseler meydana getirilmiştir. Şemselerden örgülü geçmelerle kartuşlar yapılmış ve bu kartuşların içine yazı yerleştirilmiştir. Geri kalan bölmeler ise rumi ve palmetlerle simetrik biçimde bezenmiştir. Kubbe eteğinde yazı kuşağı olması gereken yerde rokoko tarzı kıvrık dal süslemesi onarım eki olarak bırakılmıştır. Pandantiflerdeki madalyonların içleri de rumi ve palmetlerle dolgulanmıştır. (Res.22)

Kubbe No.A.20: Ortada bir madalyon ışınsal altılı şemseler ve şemselerin arasındaki dikdörtgen formatlı kartuşlardan oluşmuş bir düzenlemededir. Şemselerin içinde rumili hatayili süslemeler vardır. Kartuşların içinde ise nesih karakterli yazılar bulunur. Zeminde aralarda yer yer yanlış yorumlanmış hatayi ve palmet motiflerine rastlanmaktadır. Kubbe eteğinde en uçta kartuşlar içinde yazı bulunmaktadır. Pandantifler arasında vazodan çıkan rokoko tarzı süslemeler görülmektedir. Pandantifler ve kemerler arasındaki süslemelerin bir kısmı onarım eki olarak korunmuştur. (Res.23)

Kubbe No.A.21: Ana şema yine 1şınsal altılı simetrik tertiptedir. Dügüümlü ikiz şeritlerin meydana getirdiği şemse ve kartuş bölmelerin içleri yazı ve bozulmuş hatayilerle 
bezenmiştir. Kubbe çevresindeki rokoko bordür kaldırılmıștır. Merkezdeki yıldız onarım eseridir. Etekteki kufi ve nesih bileşimi yazı kuşağı ise devrine uygundur. Pandantiflerde daire madalyonlar içinde haçvari eksene göre simetrik palmet bölmeli rumili aynı desen tekrarlanır. Pandantiflerde kemerler arasındaki bölümlerde ise rokoko tarzı süslemeler görülür. Hatayi ve rumilerin formu bozulmuştur. Burada da madalyon içindeki bazı palmet ve dügümler, kemerler içindeki rumi ve hatayiler onarım eki olarak korunmuşlardır. (Res.24)

Kubbe No.A.22: Kubbe süslemesinde sekizli ışınsal simetrik düzende palmet şeklinde zemin bölmesi görülür. Ancak, motiflerin işlenişinden onarım sırasında boyandıkları açıkça bellidir. Ortadaki madalyon ve kubbe eteğindeki bordür boş bırakılmıştır. Pandantifteki yazılar devir üslubuna yabancıdır. (Res.25)

Kubbe No.H.1:(Mihrap önü kubbesi ) Bu kubbede ana şema ortada bir madalyon ve etrafında ışınsal düzende yerleştirilmiş şemseli kartuşlardan meydana gelir. Yıldız Demiriz 1961 de bu yapıyı incelediği zaman bu kubbede henüz çalışmalar başlamış orijinal kalem işlerinden sadece yazı kuşağının görüldüğünü kaydetmiştir. Merkezdeki madalyon içerisinde kıvrık dallı süslemeler rumiler palmetler ve hatayiler görülür. Şemse biçimli kartuşlar toplam 12 tanedir. Bunların içi rumi, palmet ve hatayilerle doldurulmuştur. Madalyonun içinde şemse biçimli kartuşların hemen bitiminde yer alan ve nöbetleşe devam eden kartuşların içinde bir tanesi rumi ve palmetle bezenirken diğeri daha geç

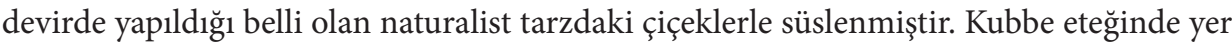
alan yazı kuşağı dikdörtgen formlu kartuş ve aradaki şemse biçimli kartuşlardan meydana gelir. Bu yazı kuşağı orjinaldir. Bu kubbede de yine düğümlü çift örgülü şeritler kartuşları ve şemseleri oluşturmaktadır. (Res.26,27) Mihrap önü kubbesini taşıyan altıgen baldakenin kemerlerinin yüzeyinde sıva raspası altından çıkan sülüs yazı kuşağı korunmuştur. (Res.28) Kubbe eteğinde ve mukarnaslar üzerinde görülen mermer taklidi süslemeler onarım ürünüdürler. (Res.29) Baldakenin mihrap nişini kuşatan kemerinin sınırladığı kıble duvarı üzerinde de kalem işleri vardır. Mihrap duvarındaki süslemelerde rumi, palmet ve penç türünde hatayiler görülür. Kartuş şeklindeki kitabe kuşağının üzerindeki süsleme devrine uygundur. Fakat kenardaki karanfilli süslemeler devrine uygun değildir. (Res.30) Mihrap duvarının üzerinde geometrik düzenleme görülür. Çokgenlerden oluşan bu düzenleme devrine uygundur. Ama yandaki bordürde görülen kıvrık dallı süsleme onarım ürünüdür. (Res. 31)

Kubbe No.H.2: Mihrap önü kubbesini taşıyan baldaken ile kuzeydoğu köşedeki küçük kubbenin arasında kalan üçgen alanların örtü sisteminde yer alan kalemişlerinde çift şeritlerin oluşturduğu kartuşlar merkezde altı kollu yıldızı meydana getirirler. Kartuşların içinde hatayiden çıkan penç ve gonca güller yer alır. Pencere aralarında ise merkezinde hatayi bulunan bitkisel karakterli devrine uymayan süslemeler görülür. Tromplar üzerinde yer alan boşluklarda, mermer taklidi süslemeler ve şekli bozulmuş kartuşlar görülür. (Res.32)

Kubbe No.H.3: Mihrap önü kubbesini taşıyan baldaken ile güneydoğu köşedeki küçük 
kubbenin arasında kalan üçgen alanların örtü sistemindeki kalemişlerinde rumi ve palmetlerden gelişen kompozisyonun uçlarından çıkan dallar ortada altı kollu yıldız şemasını oluştururlar. Boşluklarda mermer taklitleri, geometrik formlar, çizgi ve noktalamalardan oluşan süslemeler görülür. (Res.33)

Kubbe No.H.4: Mihrap önü kubbesini taşıyan baldaken ile güneybatı köşedeki küçük kubbenin arasında kalan üçgen alanların örtü sistemindeki kalemişlerinde ise rumi ve palmetlerin oluşturduğu kompozisyonun uçlarından çıkan dallar ortada oniki kollu yıldızı meydana getirmiş, ortasına da oniki kollu çiçeğe benzer bir madalyon yerleştirildiği görülmektedir. Geri kalan yüzeylerde haç ve yıldız formları, çizgi ve noktalamalar yer alır. Ayrıca burada sonraki onarımlarda yerleştirilmiş olan cami tasviri de görülmektedir. (Res.34,35)

Kubbe No.H.5: Mihrap önü kubbesini taşıyan baldaken ile kuzeybatı köşedeki küçük kubbenin arasında kalan üçgen alanların örtü sisteminde de kalemişleri vardır. Çift hatlı beyaz şeritlerden oluşan dügümlü kartuşlar görülür. Merkezde ise altı kollu yıldız motifi dikkati çeker. Kartuşların içi penç ve goncagüler ile doldurulmuştur. Etrafında ise onarım ürünleri olan mermer taklitleri, şekli bozulmuş kartuşlar, çizgi ve noktalamalardan oluşan süsleme vardır. (Res.36)

Kubbe No.H.6: Kuzeydoğu köşede yer alan kubbede rumi ve palmet bezemeli süslemeler vardır. Bunlar ortada sekiz kollu yıldızı meydana getirirler. Rumi ve palmetlerin yerleşme biçimi devrine uygundur. Kubbe eteğinde yazı kuşağı bulunmaktadır. Tromplar üzerinde ise devrine uymayan rokoko tarzı çiçekler yer alır. (Res.37)

Kubbe No.H.7: Güneydoğu köşede yer alan kubbede tamamıyla bir onarım söz konusudur. Ana şema özelliğini kaybetmiştir. Kubbe eteğinden başlayarak merkeze doğru incelen bir süsleme anlayışındadır. Rokoko süslemeler yoğunluktadır. (Res.38)

Kubbe No.H.8: Güney batı köşedeki kubbe, Kubbe no H 7 ile aynı düzendedir. Fakat kubbe eteği burada dilimli bir şekilde yapılmıştır. Tamamen yenilenmiştir. (Res.39)

Kubbe No.H.9: Kuzeybatı köşedeki kubbede rumili ve palmetli süslemeler bulunmaktadır. Diğerlerine nazaran ana şema korunmaya çalışılmıştır. Kubbe eteğinde yazı kuşağı da bulunmaktadır. Tromplarda ise tamamen yenilenmiş rokoko tarzı süslemeler yapılmıştır. (Res.40)

\section{DEĞERLENDİRME VE SONUÇ}

Erken Osmanlı mimarisinde ilk olarak İznik Kırgızlar Türbesinde gördüğümüz kuru sıva üzerine kalemişi süslemeler Bilecik Orhan Gazi imareti, Bursa Yeşil Camii, Edirne Muradiye, Tire Yeşil İmaret gibi yapılarda devam etmiştir. ${ }^{24}$ Edirne Üç Şerefeli Camii de

24- Z. Uysal, “Tire Yeşil İmaret'in Kalemişi Süslemeleri”, Sanat Tarihi Araştırmaları, Prof. Dr. Haşim Karpuz'a Armağan, (Ed. Mustafa Denktaş-Osman Eravşar), Kayseri 2007, s.351. 
bu dönemde inşa edilen önemli yapılardan biridir.

Mimaride tamamen orjinal haliyle günümüze gelmiş kalemişi süslemeleri tespit etmek oldukça güçtür. Bu durumun sebepleri arasında aydınlatma için kullanılan malzemelerin verdiği zararlar, yapılan onarımlarda özgün süslemelerin yok edilmesi ya da yanlış yorumlanması, 1slanma, depremler, yangınlar, sayılmaktadır. ${ }^{25}$

Edirne Üç Şerefeli Camii, birkaç kez onarım görmesine rağmen, hala duvar yüzeylerinde ve kubbelerin bir bölümünde dönemine ait kalem işi süslemeleri muhafaza etmektedir. Osmanlı döneminde sıva üzerine uygulanan kalem işlerinin kuru sıva üzerine uygulandığ bilinmektedir. ${ }^{26}$ Bu niteliği Üç Şerefeli Cami’nin kubbelerinde de tespit etmek mümkündür. Yapıda, yer yer sıvası dökülmüş kısımlarda boyaların yüzeyde kaldığı ve derine nüfuz etmediği gözlemlenebilmektedir.

Renklerde Yıldız Demiriz, lacivert zemin üzerine sarı ve beyaz motifler işlenmiştir demektedir ${ }^{27}$. Ama buradaki renkler yapılan onarımlar sonucunda 15.yüzyıl renk anlayışından uzaklaşmıştır. Nakkaşlar, yapının üzerinde belirleyebildikleri kadarıyla orijinal desenlerin üzerinden geçmişlerdir. Büyük bir oranda motiflerin renkleri farklı tonlarda boyanmıştır. Parlak mavi, kırmızı, sarı ve beyaz, lacivert renk tonlarının yerini koyu kahve, haki yeşil, gibi renkler almıştır. Özellikle mavi zemin üzerine beyaz renk kubbe eteğindeki yazı kuşaklarında tercih edilmiştir. Genelde pastel tonları hakimdir. Ama renkler matlaşmıştır. Yer yer de rumilerin içlerinde farklı renk tonları kullanılarak barok etki yaratılmıştır. Bu da son onarımlardan kaynaklanmaktadır.

Revak kubbelerinde belli ölçüde orijinalliğini koruyabilmiş olanlarda ana şema şu şekildedir. Merkezden kubbe eteğine doğru 1şınsal düzende dağılan, düğümlü çift şeritlerle çerçevelenmiş şemse veya kartuşlardan oluşur. Bunların arasında benzer düzende dağılan daha küçük kartuşlar da yer alabilir. Büyük kartuşlarda kompozisyonun ana temasını kıvrık dallı simetrik rumi ve palmet motifleri oluşturur. Aradaki küçük kartuşlarda bazen nöbetleşe olarak rumi, palmet, hatayi kompozisyonu kullanılabilmektedir. Hatayiler üzerinden dikkatsiz geçildiği için asli karakterlerini kaybetmişler ve yelpazeli çiçeklere benzemişlerdir. Bazı kubbelerde küçük kartuşlarda görülen natüralist üsluptaki çiçek buketleri batılılaşma dönemi onarımına işaret eder. Özellikle pandantiflerde 18. yüzyıl onarımını açıkça gösteren rokoko üsluplu süslemeler vardır. Revak kubbelerinin içinde kubbe merkezinde bazen geometrik geçme bazen de dört altı, sekiz, oniki kollu yıldızlar yer almaktadır. Ortada geometrik geçme uygulamasını Edirne Eski Camiinde de de görmekteyiz. Edirne Muradiye Camiinin kubbe tezyinatında ve kemer içlerinde de geometrik dügüm ve geçmeleri görürüz. Kubbe eteklerinde yazı kuşağından hemen

25-Bkz. S. İrteş, “Kalemişi, Cam ve Revzen”, Bir Şaheser Süleymaniye Külliyesi, (Ed. Selçuk Mülayim), Kültür ve Turizm Bakanlığı Yayınları, Ankara 2007, s.294. Y. Demiriz, “Osmanlı Kalem İşleri”,Osmanll, C. 11, s.297.

26-Bu konuyla ilgili olarak bkz.,C.E.Arseven, Sanat Ansiklopedisi,’Fresk Maddesi”, C. 2, Milli Eğitim Basımevi, İstanbul 1983, s.619.

27- Y .Demiriz;"Edirne Camilerinde Kalem İşleri”, Edirne Serhattaki Payitaht, (Haz. Emin Nedret İşli -M. Sabri Koz), Yapı Kredi Yayınları, İstanbul 1998, s.379.. 
önce yer alan bordür içerisine genellikle rumi - palmet dizisi yerleştirilir. Türk Sanatında rumi-palmet, lotus-palmet uygulamalarına bordürler içerisinde rastlamak mümkündür. Özellikle Selçuklu taş işçiliğinde yoğun olmakla beraber Beylikler devrinde inşa edilmiş ahşap üzerine kalemişi süslemelerin görüldüğü yapılarda rumi palmet uygulamalarının yanında rumi hatayi ve kıvrık dallar şeklinde süslemelerle de karşılaşıyoruz. ${ }^{28}$ Üç Şerefeli Cami'de bu bordürlerin bir kısmı bozulmuş, bir kısmı yanlış anlaşılmış bazılarının yerine de mermer taklidi süslemeler yerleştirilmiştir. Kubbe içlerinde gördüğümüz çift şeritler geometrik düğümler için orjinal ve devrine uygun olduğunu söyleyebiliriz. Süheyl Ünver bunların bazılarının çizimlerine makalesinde yer vermiştir. ${ }^{29}$ Düğümler Bursa Yeşil Cami çinilerinde de görülmektedir.

Kubbe süslemelerinde yer alan merkezi kompozisyonlarda ortada bir göbek ve göbeğin etrafında bir veya daha fazla bordür kullanılması yaygındır. ${ }^{30}$ Kubbe içlerindeki madalyon esaslı bezemeler ve bu madalyonların içlerindeki ışınsal dört, altı, sekiz, oniki eksenli simetrik dağılım kompozisyonun ana fikri bakımından Tire Yeşil İmaret, Bursa Muradiye Cami, Edirne Muradiye Cami, gibi yapılarla paralellikler gösterir. ${ }^{31}$

Merkezi kubbede de ana hatlarıyla motif ve kompozisyon devrin özelliklerini taşımaktadır. Fakat renk müdahalesi burada da söz konusudur. Benzer durum kemerlerdeki yazılarda ve kalem işlerinde de geçerlidir. Merkezi kompozisyonda ortada bir madalyon etrafında ışınsal düzende yerleştirilmiş şemseli kartuşlar görülür. Bunların içi rumi, palmet ve hatayilerle doldurulmuştur. Madalyonun içinde şemse biçimli kartuşların bazılarında devrine uygun olarak rumi palmet düzenlemesi görülürken, bazılarında daha geç devirde yapıldığ belli olan naturalist tarzdaki çiçekler dikkati çekmektedir. Kubbe eteğinde yer alan kartuş şeklindeki süslemeler Beylikler devrinden itibaren süsleme sanatlarında yoğun bir şekilde görülmektedir. Özellikle dilimli kemerli kartuş uygulaması, bu kartuşların içinde kıvrık dallı rumiler, ortada basit bir palmet veya geometrik geçme ya da dügüm, bazen hatayi görülmesi tipiktir. Süreklilik gösteren kartuşlu bitkisel kompozisyonlar Beylikler devrinin tezhip ve minyatürlerindeki bordürlerde de kullanılmıştır. ${ }^{32}$ Ankara'da 15. yüzyılda ahşap direkli olarak inşa edilen yapılarda da bu tarz süslemeleri görmekteyiz. ${ }^{33}$ Ayrıca

28-S. Ögel, Anadolu Selçuklularının Taş Tezyinatı, Türk Tarih Kurumu Yayınları Ankara,1966, s. 75-77; Z. Uysal, Ankara Mescitlerine Kalem İşi Süslemeler XIV.-XV. Yüzyıl, Çanakkale Onsekiz Mart Üniversitesi Sosyal Bilimler Enstitüsü (Yayınlanmamış Yüksek Lisans Tezi), Çanakkale 2001; Z. Uysal, "XVI-XV. Yüzyıl Ankara Mescitlerinde Kalem İşi Süslemeler”, Uluslararası Sanat Tarihi Sempozyumu, Prof. Dr. Gönül Öney'e Armağan, 10-13 Ekim 2001, İzmir 2002, s. 579-590; Z. Uysal, "Das Spiel der Farben, Blüten pracht auf Holz ziert die frühen Gebetshäuser in Ankara”, Antike Welt, Helf 5, 2004, 87-91; Y. Erdemir, Beyşehir Eşrafoğlu Süleyman Bey Camii ve Külliyesi, Beyşehir Vakfı Yayınları, Beyşehir 1999,s.53,57,65; Candan Nemlioğlu, "Çarşamba Gökçeli Camii”, I. Uluslararası Selçuklu Kültür ve Medeniyeti Kongresi, (11-13 Ekim 2000, Konya), C. II, Konya 2001,s.125.

29-S. Ünver, “Edirne’de Üç Şerefeli Camiin Avlusu Kubbeleri İçindeki Devrinin Süsleri Hakkında”, Arkitekt, S. 07-10, 1949, s. 168.

30-Y. Demiriz, Osmanlı Mimarisinde Süsleme,I, s. 35.

31-Z. Uysal, “Tire Yeşil İmaretin Kalemişi Süslemeleri”, s. 351.

32-S. Bayram, "XIV. Asırda Tezhiplenmiş Beylik Dönemine Ait Üç Kuran Cüzü”, Vakıflar Dergisi, Sayı. XVI, Vakıflar Genel Müdürlüğü Yayınları, Ankara 1982, s.149, Res. 5,6.

33-Z. Uysal, Ankara Mescitlerinde Kalem İşi Süslemeler (XIV-XV.Yüzyıl ), s.114. 
Şemseli bitkisel kompozisyonları bu dönemde bazen bir minyatürlü yazmada bazen de bir kubbenin içerisindeki süslemede görmek mümkündür. ${ }^{34}$ Kubbe eteğinde yer alan yazı kuşağ 1 dikdörtgen formlu kartuş ve aradaki şemse biçimli kartuşlardan meydana gelir. Bu yazı kuşağı orjinaldir. Bu kubbede de yine dügümlü çift örgülü şeritler kartuşları ve şemseleri oluşturmaktadır. Mihrap önü kubbesini taşıyan altıgen baldakenin kemerlerinin yüzeyinde sıva raspası altından çıkan sülüs yazı kuşağı korunmuştur. Kubbe eteğinde ve mukarnaslar üzerinde görülen mermer taklidi süslemeler onarım ürünüdürler. Baldakenin mihrap nişini kuşatan kemerinin sınırladığı kıble duvarı üzerinde de kalem işleri vardır. Mihrap duvarındaki süslemelerde rumi, palmet ve penç türünde hatayiler görülür. Kartuş şeklindeki kitabe kuşağının üzerindeki süsleme devrine uygundur. Fakat kenardaki karanfilli süslemeler devrine uygun değildir. Bu rumi, palmet, hatayili tarzdaki süslemeyi Bursa Yeşil Cami’nin müezzin mahfili duvar çinilerinde görürüz.

Mihrap duvarının üzerinde görülen çokgenlerden oluşan geometrik düzenleme devrine uygundur. Fakat onarımlar sonucunda renk değişiklikleri dikkati çeker. E.H.Ayverdi, bu tezyinatın 1931 yılında Sideris isimli bir boyacıya yaptırıldı ğını ifade etmektedir. ${ }^{35}$ Fakat bu tarz süsleme Selçuklu döneminde inşa edilen, Karatay medresesi eyvanının arka duvarında ve Sırçalı medresesinin ana eyvanında çini süsleme olarak kullanılmıştır. Şema olarak sekiz kollu yıldız tasarımıdır. Aynı tarz süsleme Bursa Yeşil Cami çini süslemelerinde de görülür. Dolayısıyla önceden var olan bu süslemenin üzerinden geçilerek renk değişikliği yapılmış olması kuvvetle muhtemeldir.

Harimin kuzeydoğu köşesinde yer alan kubbede rumi ve palmet bezemeli süslemeler vardır. Bunlar ortada sekiz kollu yıldızı meydana getirirler. Rumi ve palmetlerin yerleşme biçimi devrine uygundur. Kubbe eteğinde yazı kuşağı bulunmaktadır. Tromplar üzerinde ise devrine uymayan rokoko tarzı çiçekler yer alır. Kuzeybatı köşedeki kubbede rumili ve palmetli süslemeler bulunmaktadır. Diğerlerine nazaran ana şema korunmaya çalışılmıştır. Kubbe eteğinde yazı kuşağı da bulunmaktadır. Tromplarda ise tamamen yenilenmiş rokoko tarzı süslemeler yapılmıştır. Güneydoğu köşede yer alan kubbede tamamıyla bir onarım söz konusudur. Ana şema özelliğini kaybetmiştir. Kubbe eteğinden başlayarak merkeze doğru incelen bir süsleme anlayıșındadır. Rokoko süslemeler yoğunluktadır. Güney batı köşedeki kubbe de benzer düzendedir. Tamamen yenilenmiştir.

Üçgen alanlarda ana şema korunmaya çalışılsa da buradaki süslemeler de yenilenmiştir. Güneydoğu ve güneybatıdaki alanlarda nispeten daha erken tarihli bir müdahale söz konusudur. Kuzeybatı ve kuzeydoğudaki üçgen alanlarda ise daha geç müdahaleler göze çarpar. Tromplarda yine diğerleriyle aynı tarzda yapılmış rokoko süslemeleri görürüz.

Araştırmacılara göre Erken Osmanlı dönemine tarihlenen yapıların restorasyonu sırasında yazıların üzerinden bilinçsizce geçilmesi sonucu yazıların yapısı bozulmuştur. ${ }^{36}$ Üç Şerefeli

34-F. Çağman-Z. Tanındı, Topkapı Saray Museum Islamic Miniature Painting, Art and Cultural Publications, İstanbul 1979, Figure 16, No.37.

35- E.H. Ayverdi, a.g.e., s.447.

36- A. Tüfekçioğlu, Erken Dönem Osmanlı Mimarisinde Yazı, Kültür Bakanlığı Yayınları, Ankara 2001, s.490. 
Cami’nin ana kubbe haricindeki diğer harim kubbe yazılarının sonradan yapıldığı ifade edilmektedir. ${ }^{37}$ A.Fuat Baysal, Edirne Üç Şerefeli Cami'nin avlu revaklarında bulunan yazıları incelediği araştırmasında revaklı avlunun 14 kubbesinde yazı bulunduğunu bunlardan 12 tanesinde orjinal yazılar görüldügünü belirtmektedir. ${ }^{38}$ Kemerlerde, kubbe eteklerinde, gördüğümüz mermer taklidi süslemeler sonradan ilave edilmişlerdir.

Sonuç olarak Edirne Üç Şerefeli Cami’ndeki kalem işi süslemelerin bir bölümü devrinin ana kompozisyonunu korumaktadır. Ancak yapının harim ve revaklarındaki kubbelerin bazılarında, Geç Osmanlı dönemi onarımlarının ürünü olan Barok, Rokoko tarzı süslemeler özgün kompozisyonların yerini almıştır. Onarımlar sırasında birçok kez desenlerin üzerinden boyalarla geçilmesi motifleri kabarık bir hale getirmiştir. 


\section{KAYNAKÇA}

Ahmed Bâdî Efendi, Riyâz-I Belde-I Edirne (20. Yüzyıla Kadar Osmanlı Edirnesi), Trakya Üniversitesi Yayınları, İstanbul 2014.

Altınsoy Mercimek, Gülşen, Edirne Camilerinde 18.Yüzyıl Onarımları, İstanbul Teknik Üniversitesi, Fen Bilimleri Enstitüsü, (Yayınlanmamış Doktora Tezi), İstanbul 1999.

Arseven, Celal Esad, Sanat Ansiklopedisi," Fresk Maddesi”, C. 2, Milli Eğitim Basımevi, İstanbul 1983.

Aslanapa, Oktay, "Edirne’de Türk Mimarisinin Gelişmesi”, Edirne: Edirne’nin 600. Fetih Yildönümü Armağan Kitabl, Ankara 1965, 223-232.

Ayverdi, Ekrem Hakkı, Osmanlı Mimarisinde Çelebi ve II. Sultan Murad Devri, C.II, İstanbul 1972.

Bayram, Sadi, "XIV. Asırda Tezhiplenmiş Beylik Dönemine Ait Üç Kuran Cüzü”, Vakıflar Dergisi, Sayı. XVI, Vakıflar Genel Müdürlüğü Yayınları, Ankara 1982, 143-154.

Baysal, Ali Fuat, Edirne Osmanlı Erken Dönem Camileri Kalemişi Örnekleri ve Analizleri, Necmettin Erbakan Üniversitesi, Sosyal Bilimler Enstitüsü, (Yayınlanmamış Doktora Tezi) Konya 2013.

Baysal, Ali Fuat, “Üç Şerefeli Camii Avlu Revaklarında Bulunan XV. Yüzyıl Kalem İşi Uygulamalı Hat Örnekleri”, İstem, Y1l:12, Sayı 23, 2014, 61-73.

Beşir Çelebi, Tarih-i Edirne: Hikayet-i Beşir Çelebi, (Haz: İ.H.Ertaylan), İstanbul Üniversitesi Edebiyat Fakültesi Yayınları, İstanbul.1960.

Çağman, Filiz - Zeren Tanındı, Topkapı Saray Museum Islamic Miniature Painting, Art and Cultural Publications, İstanbul 1979, No.37.

Demiriz, Ylldız, “Osmanlı Kalem İșleri”, Osmanlı, C.11, Ankara 1999, 297-304.

Demiriz, Yıldız, Osmanlı Mimarisinde Süsleme, I, Erken Devir (1300-1453), Kültür Bakanlığı Yayınları, İstanbul 1979.

Demiriz, Ylldız, "Edirne Camilerinde Kalem İșleri”, Edirne Serhattaki Payitaht, (Haz. Emin Nedret İșli-M. Sabri Koz), Yapı Kredi Yayınları, İstanbul 1998, 373-380.

Erdemir, Yaşar, Beyşehir Eşrefoğlu Süleyman Bey Camii ve Külliyesi, Beyșehir Vakfı Yayınları, Beyşehir 1999.

Erdoğan, Muzaffer, “Osmanlı Devrinde Yapılan İmar Çalışmaları”, Güney-Doğu Avrupa Araştırmaları Dergisi, 6-7, (1977-1978), İstanbul 1978, s.121-188.

Evliya Çelebi Seyahatnamesi, C.3, (Haz.S.A.Kahraman - Y.Dağlı) Yapı Kredi Yayınları, İstanbul 1999.

Eyice, Semavi, "Edirne”, Türkiye Diyanet Vakfı İslam Ansiklopedisi, C.10, İstanbul 1994, 431-442.

Goodwin, Godfrey, Osmanlı Mimarlğ̆ı Tarihi, Çev. M.Günay, Kabalcı Yayınevi, İstanbul 2012.

Gökbilgin, M.T. “Edirne Hakkında Yazılmış Tarihler ve Enis-ül Müsâmirîn”, Edirne: Edirne’nin 600. Fetih Yıldönümü Armağan Kitabl, Ankara 1965, 77-117.

Gökbilgin, M.T. XV-XVI. Asırlarda Edirne ve Paşa Livası, Üçler Matbaası, İstanbul 1952.

İnalcık, Halil, “Edirne’nin Fethi”, Edirne: Edirne’nin 600. Fetih Yıldönümü Armağan Kitabı, Ankara 1965, 137- 
159.

İrteş, Semih, "Kalemişi, Cam ve Revzen”, Bir Şaheser Süleymaniye Külliyesi, (Ed. Selçuk Mülayim), Kültür ve Turizm Bakanlığı Yayınları, Ankara 2007, 293-325.

Kuban, Doğan, Osmanlı Mimarisi,, Yem Yayınları, İstanbul 2007.

Kuban, Doğan, Sinan’n Sanatı ve Selimiye Tarih Vakfı Yayınları, İstanbul 1997.

Kuran, Apdullah, Mimar Sinan, Hürriyet Vakfı Yayınları, İstanbul 1986.

Menage, V.L. "Edirne’li Rûhi'ye Atfedilen Osmanlı Tarihinden İki Parça”, Ord. Prof. İsmail Hakkı Uzunçarşıllìya Armağan, Türk Tarih Kurumu Yayınları, Ankara 1976, 311-333.

Nemlioğlu, Candan, “Çarşamba Gökçeli Camii”, I. Uluslararası Selçuklu Kültür ve Medeniyeti Kongresi, (11-13 Ekim 2000, Konya), C. II, Konya 2001, 117-136.

Ögel, Semra, Anadolu Selçuklularının Taş Tezyinatı, Türk Tarih Kurumu Yayınları, Ankara 1966.

Onur, Oral, Edirne, Türk Tarihi Vesikalarından Kitabeler, Yenilik Basımevi, İstanbul 1972.

Peremeci, Osman Nuri, Edirne Tarihi, Resimli Ay Matbaası, İstanbul 1939.

Sayan, Feyza Köse, Erken Osmanlı Camileri İçinde Edirne Üç Şerefeli Cami ve Belgeler Üzerinden Cumhuriyet Dönemine Kadar Geçirdiği Onarımlar, Yıldız Teknik Üniversitesi, Fen Bilimleri Enstitüsü (Yayınlanmamış Yüksek Lisans Tezi) İstanbul 2018.

Tanman, Mehmet Baha, “Edirne’de Erken Dönem Osmanlı Camileri ve Özellikle Üç Şerefeli Cami Hakkında”, Edirne: Serhattaki Payitaht, (Haz. Emin Nedret İşli-M. Sabri Koz), Yapı Kredi Yayınları, İstanbul 1998, 325-352.

Tüfekçioğlu, Abdülhamit, Erken Dönem Osmanlı Mimarisinde Yazı, Kültür Bakanlığı Yayınları, Ankara 2001.

Uysal, Ali Osman, "Erken Osmanlı Mimarisinde Minareler", Osmanl, C.10, Yeni Türkiye Yayınları, Ankara 1999, s.137-160.

Uysal, Zekiye, Ankara Mescitlerine Kalem İşi Süslemeler XIV.-XV. Yüzyıl, Çanakkale Onsekiz Mart Üniversitesi Sosyal Bilimler Enstitüsü (Yayınlanmamış Yüksek Lisans Tezi), Çanakkale 2001.

Uysal, Zekiye "XVI-XV. Yüzyıl Ankara Mescitlerinde Kalem İşi Süslemeler", Uluslararası Sanat Tarihi Sempozyumu, Prof. Dr. Gönül Öney’e Armağan, 10-13 Ekim 2001, İzmir 2002, 579-589.

Uysal, Zekiye, "Das Spiel der Farben, Blüten pracht auf Holz ziert die frühen Gebetshäuser in Ankara”, Antike Welt, Helf 5, 2004, 87-91.

Uysal, Zekiye, “Tire Yeşil İmaret’in Kalemişi Süslemeleri”, Sanat Tarihi Araştırmaları, Prof. Dr. Haşim Karpuz’a Armağan, (Ed. Mustafa Denktaş-Osman Eravşar), Kayseri 2007, 347-357.

Ünver, Süheyl, “Edirne’de Üç Şerefeli Camiin Avlusu Kubbeleri İçindeki Devrinin Süsleri Hakkında”, Arkitekt, S. 07-10, 1949, 166-168.

Ünver, Süheyl, “Edirne Medeniyetimiz ve Tezyini Misalleri,”, Edirne: Edirne’nin 600.Fetih Yıldönümü Armă̆an Kitabi, Ankara 1965, 233-253.

Yetkin, Suut Kemal Türk Mimarisi, Bilgi Yayınları, Ankara 1970. 


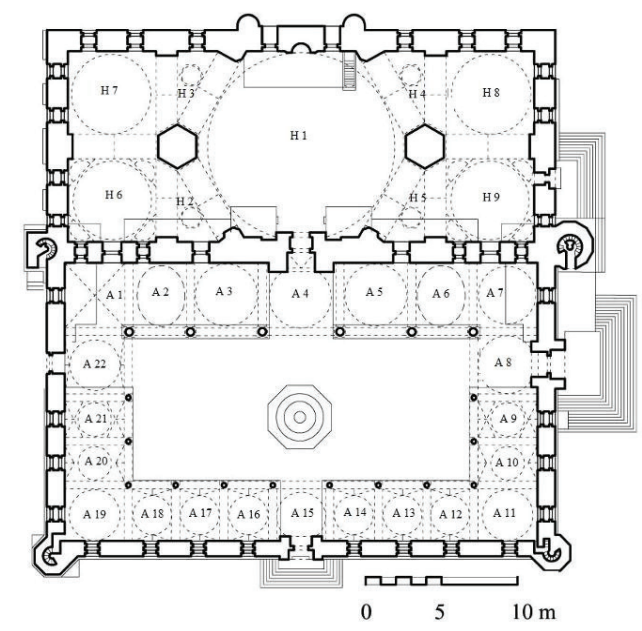

Şekil 1. Üç Şerefeli Camii planı (archnet.org - 10.02.2020)

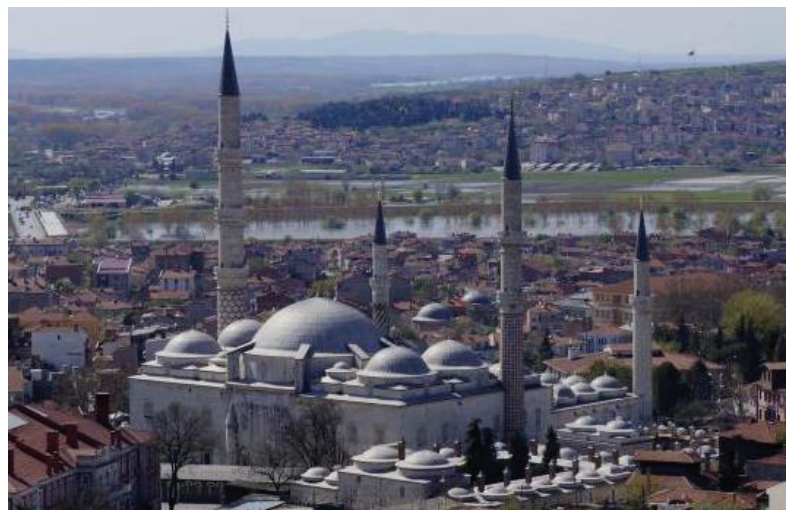

Resim 1. Genel görünüş 


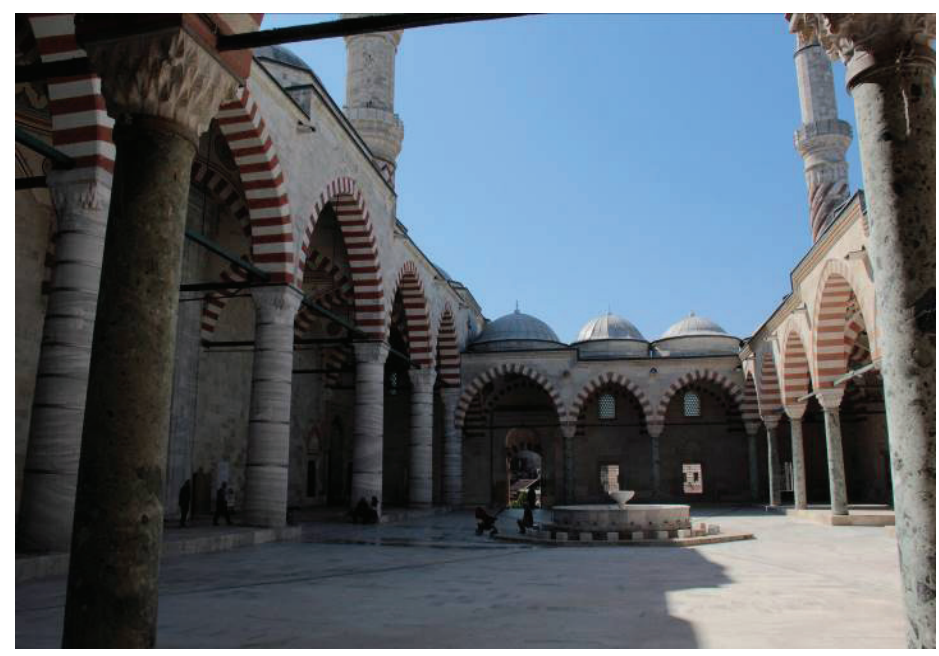

Resim 2. Revaklı avlu

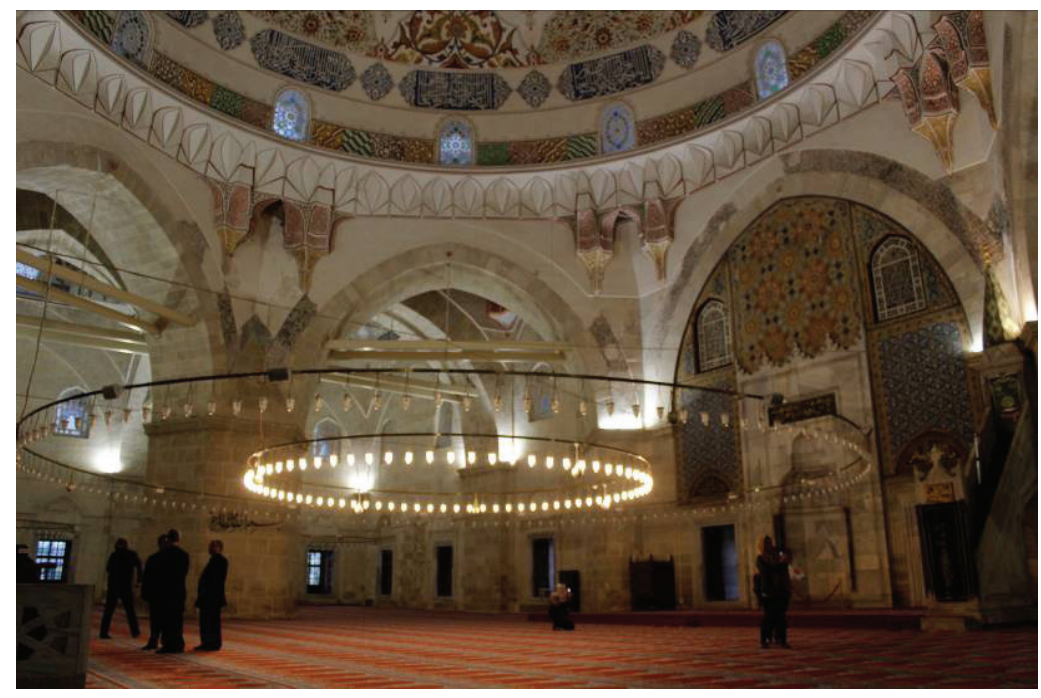

Resim 3. Harimden görünüş 


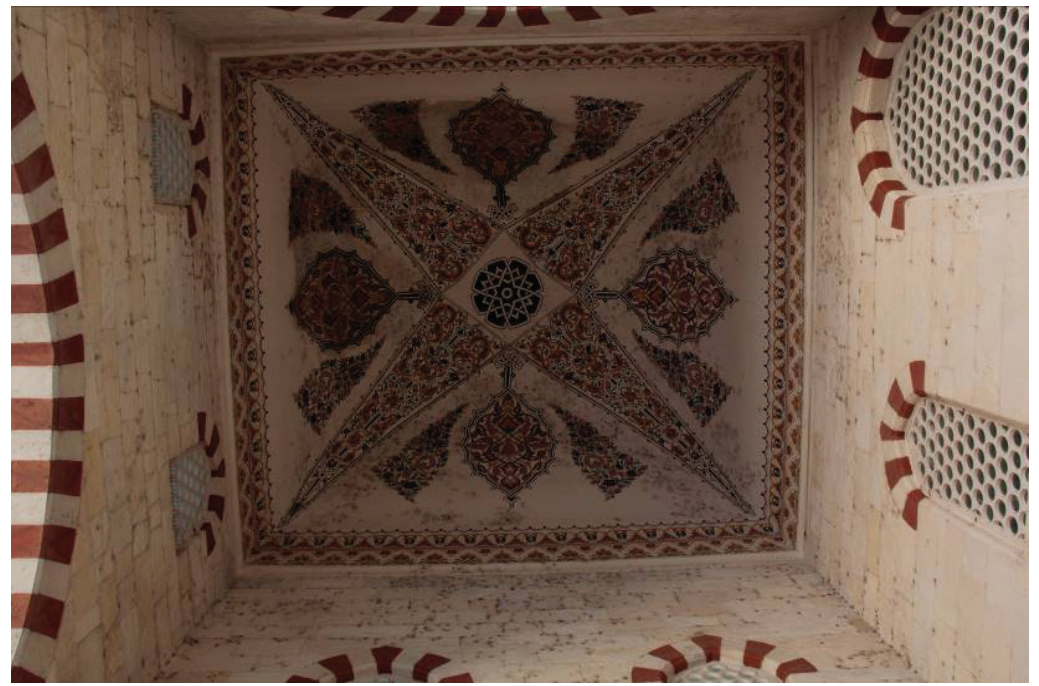

Resim 4. Kubbe No.A.1

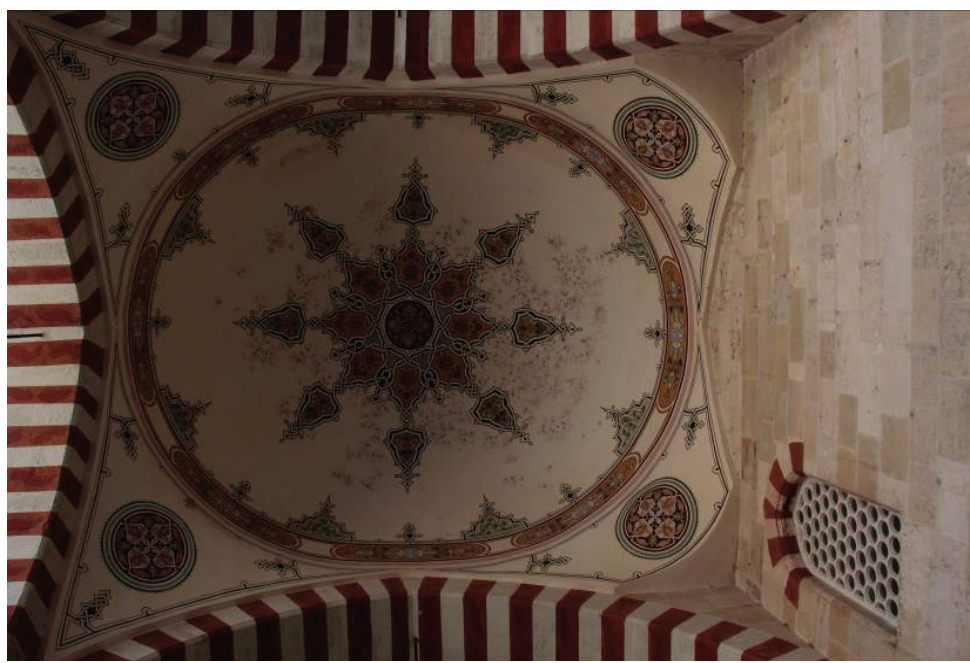

Resim 5. Kubbe No.A.2 


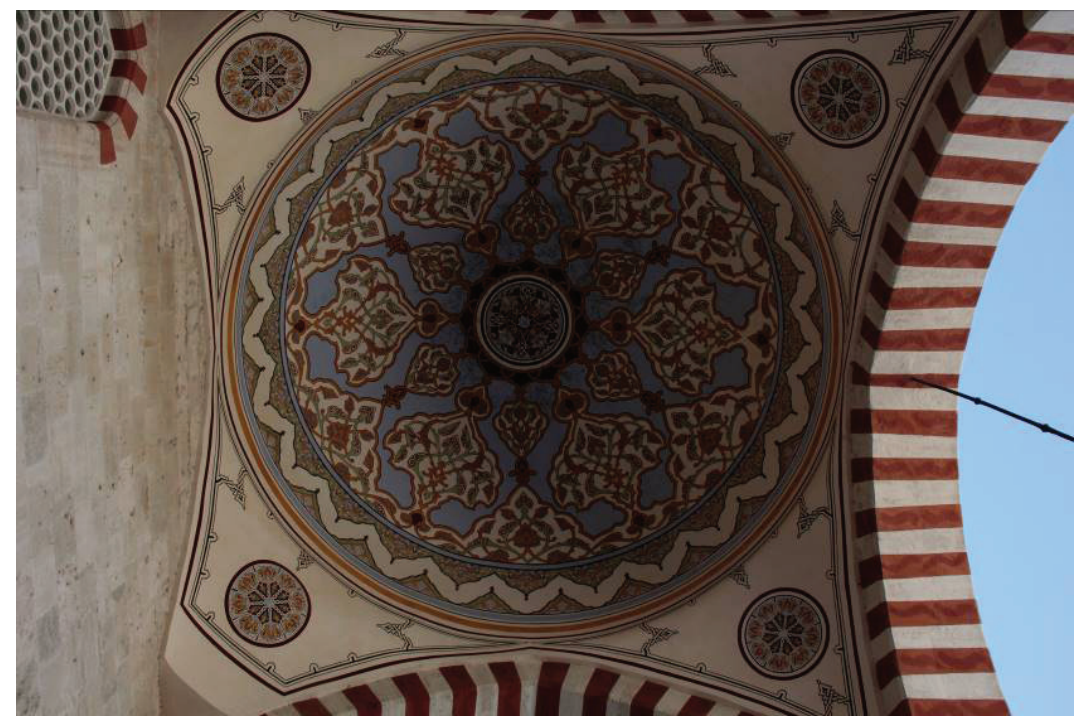

Resim 6. Kubbe No.A.3

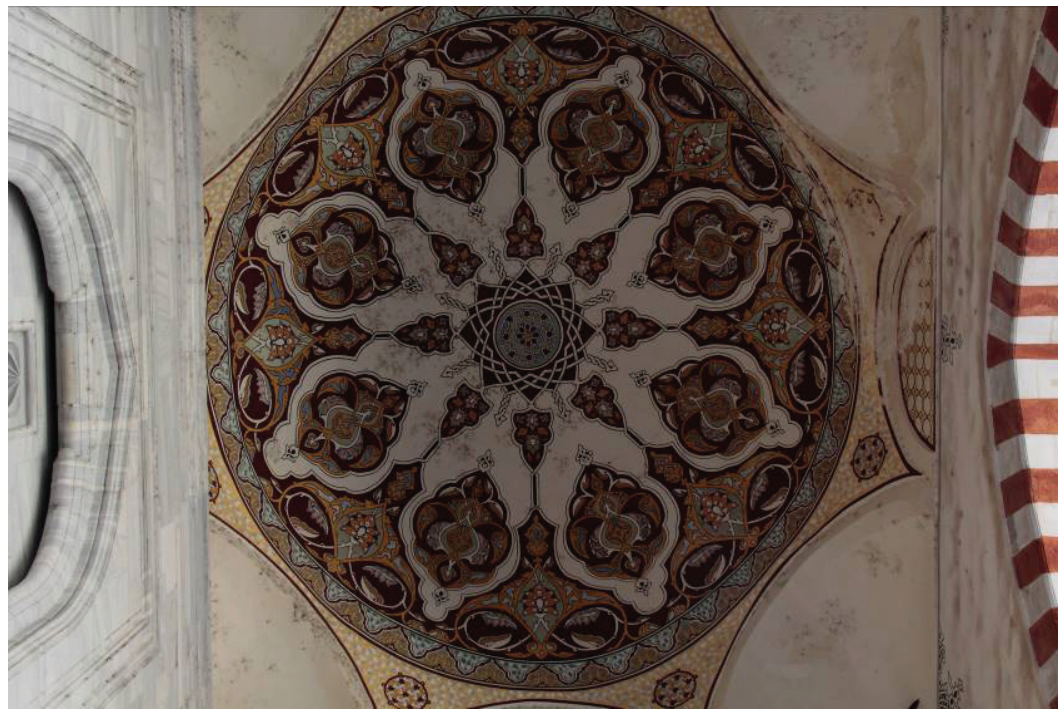

Resim 7. Kubbe No.A.4 


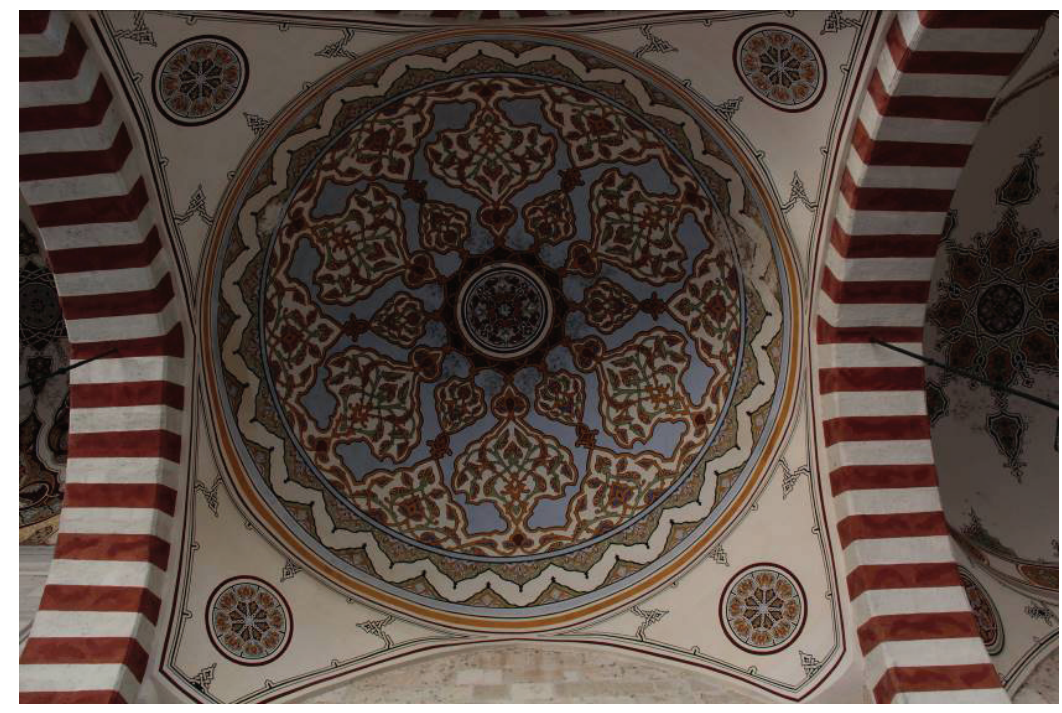

Resim 8. Kubbe No.A.5

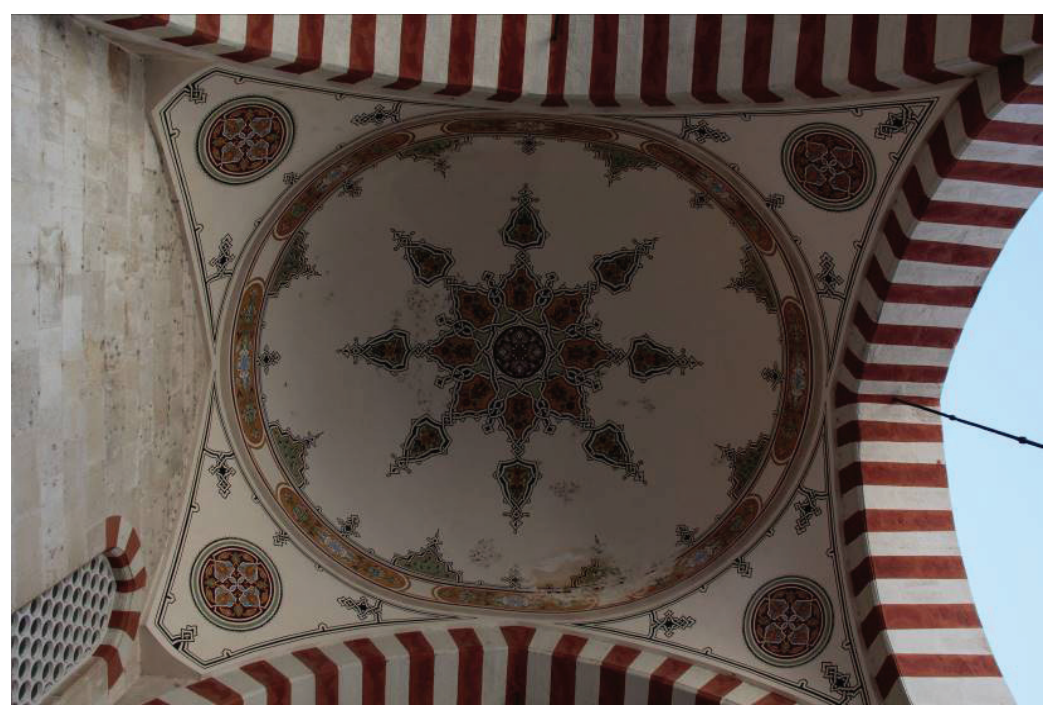

Resim 9. Kubbe No.A.6 


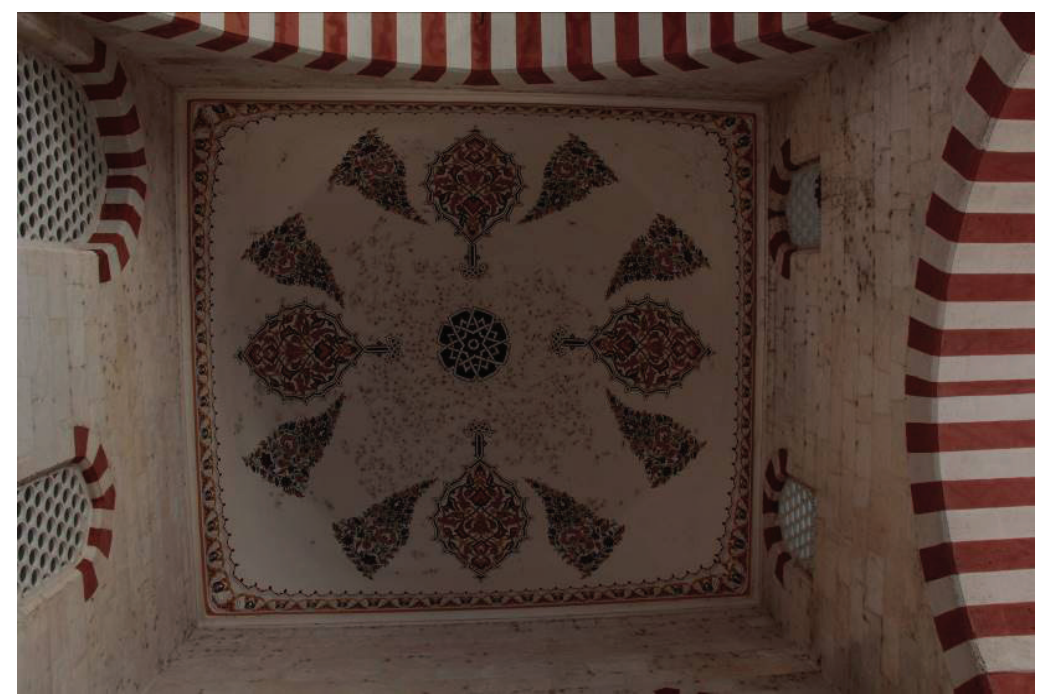

Resim 10. Kubbe No.A.7

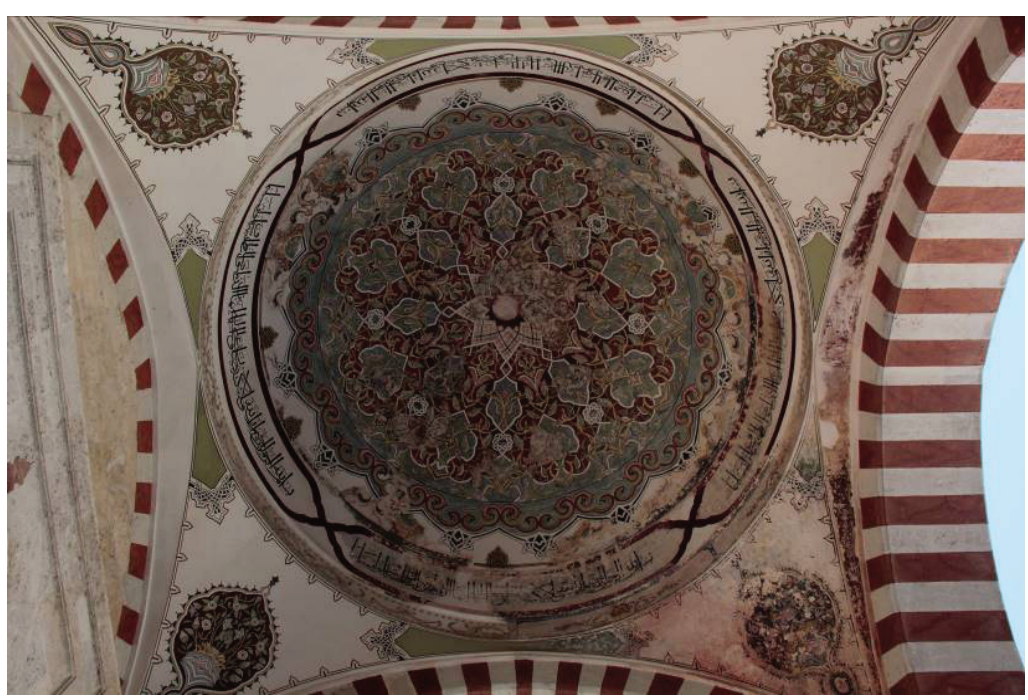

Resim 11. Kubbe No.A.8 


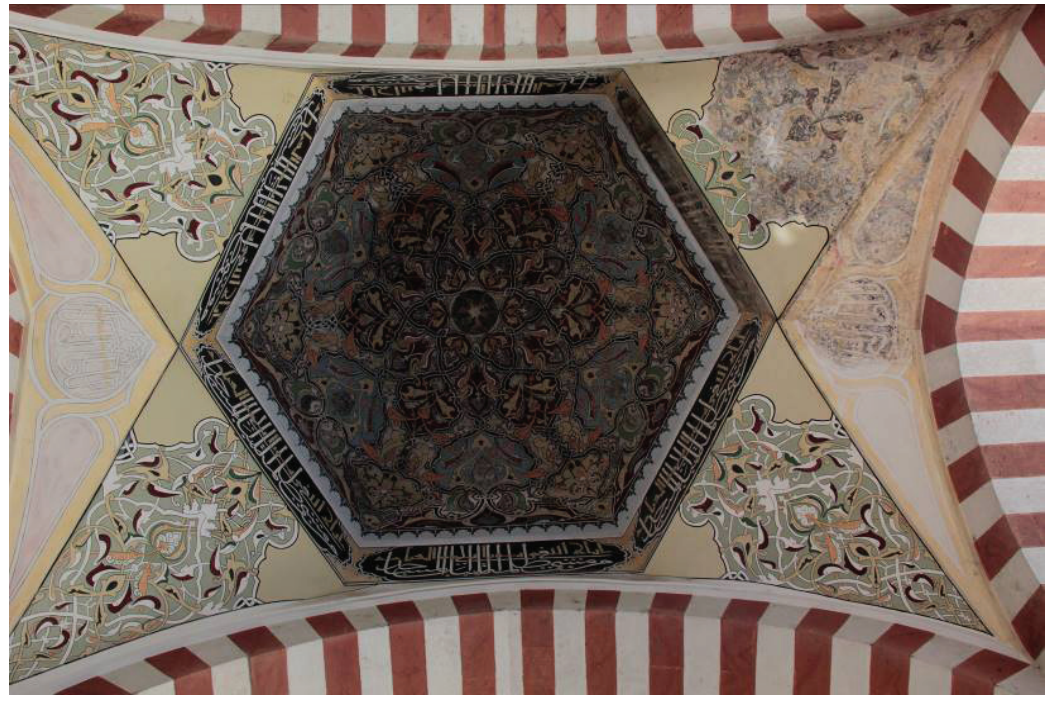

Resim 12. Kubbe No.A.9

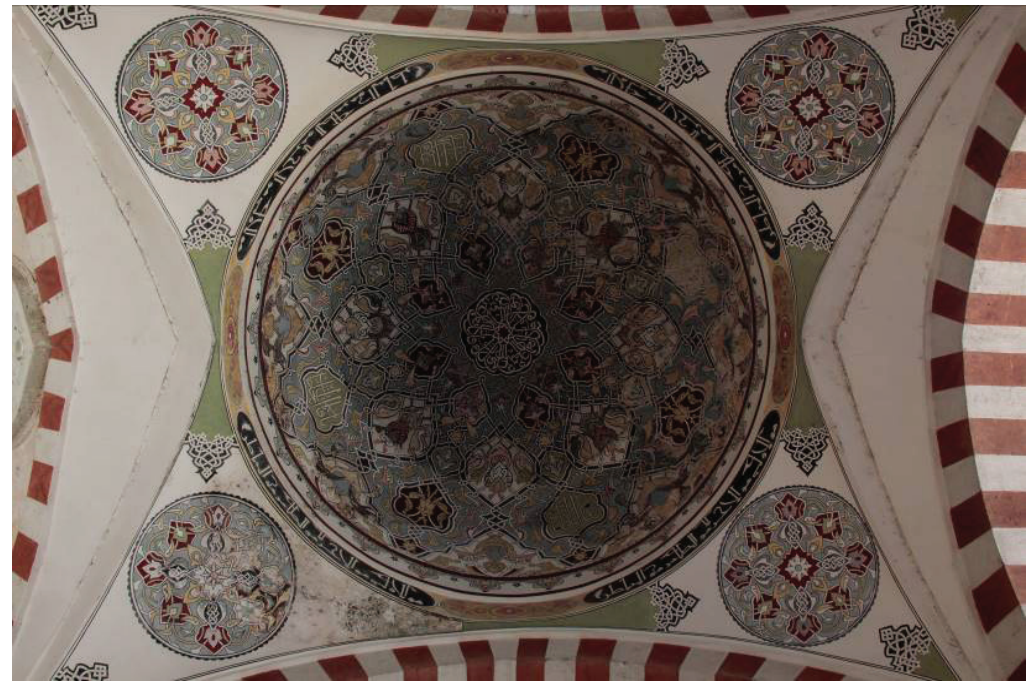

Resim 13. Kubbe No.A.10 


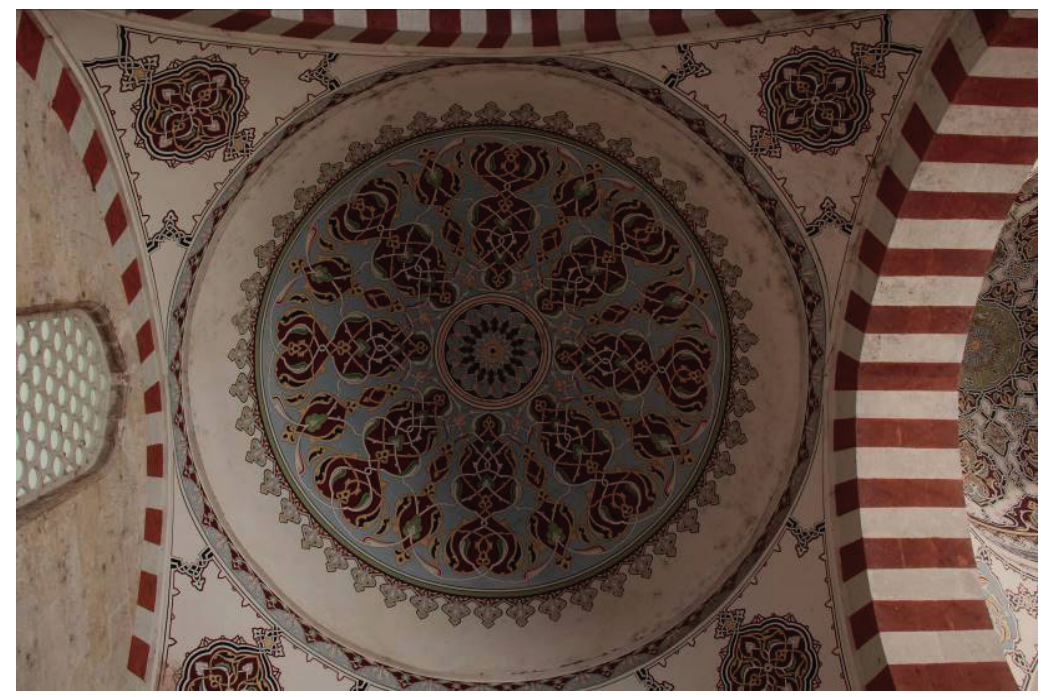

Resim 14. Kubbe No.A.11

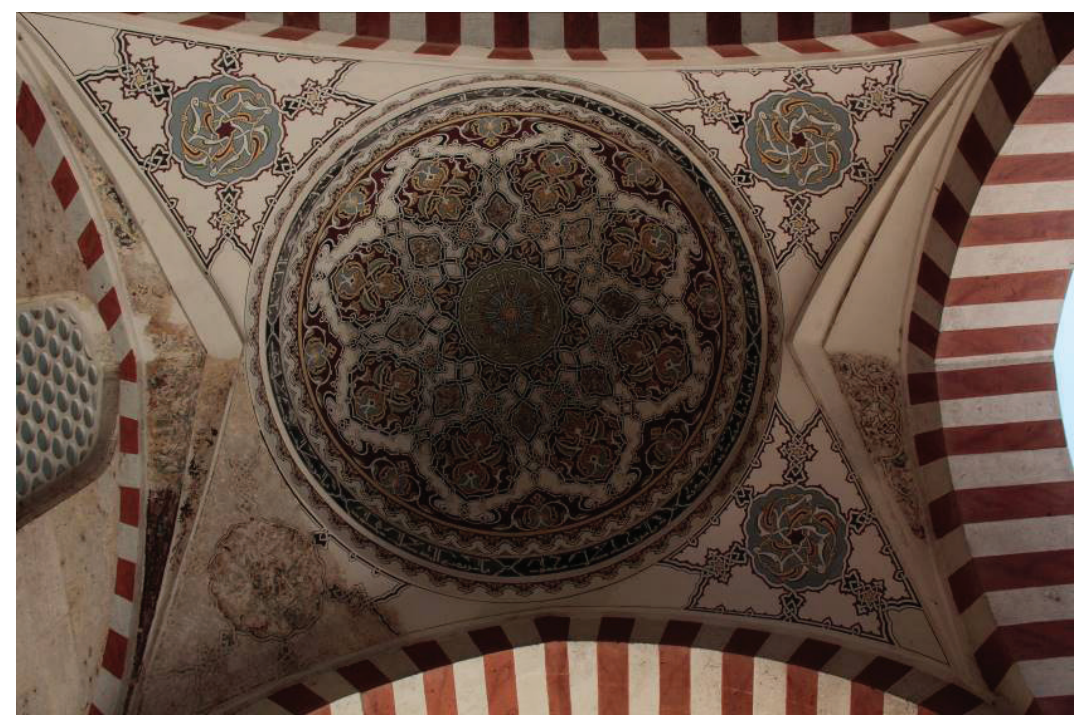

Resim 15. Kubbe No.A.12 


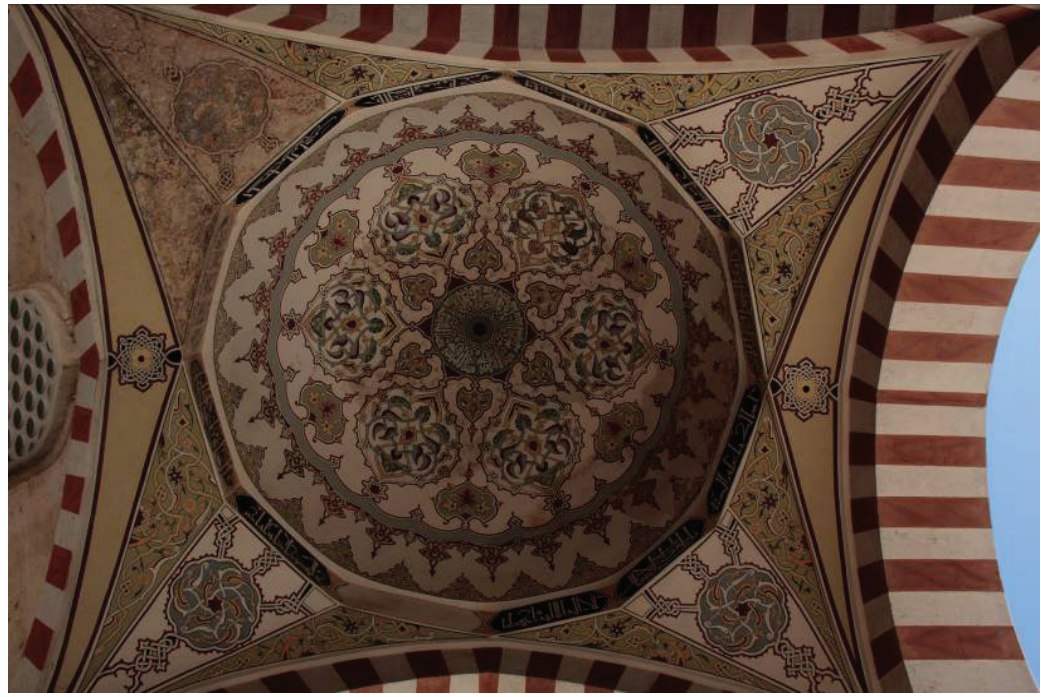

Resim 16. Kubbe No.A.13

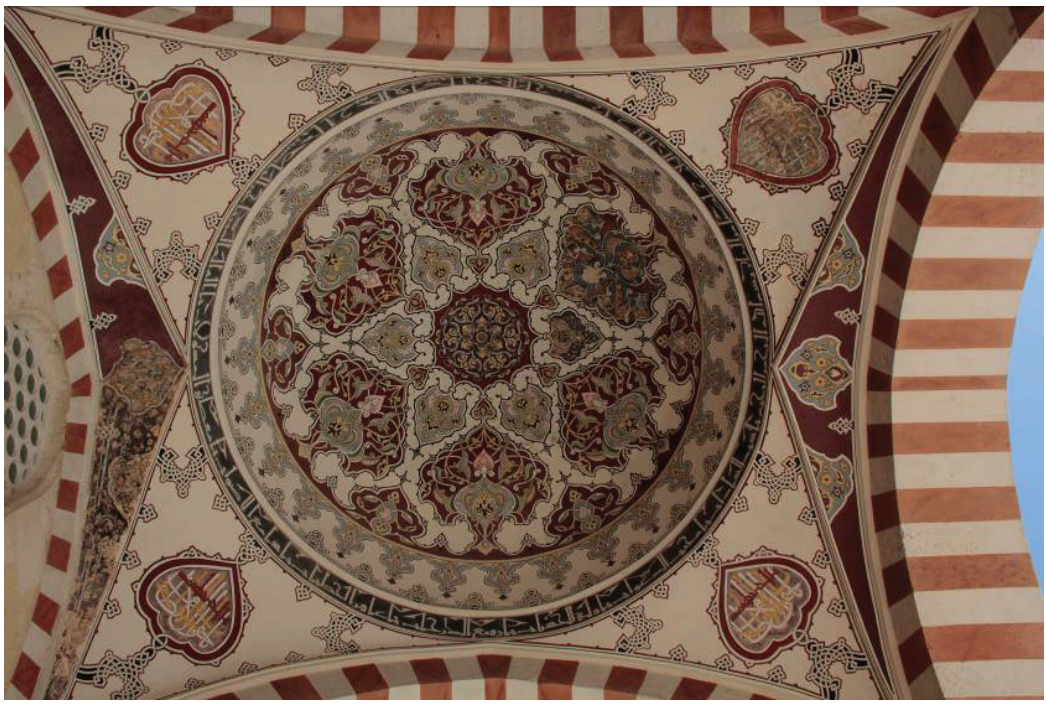

Resim 17. Kubbe No.A.14 


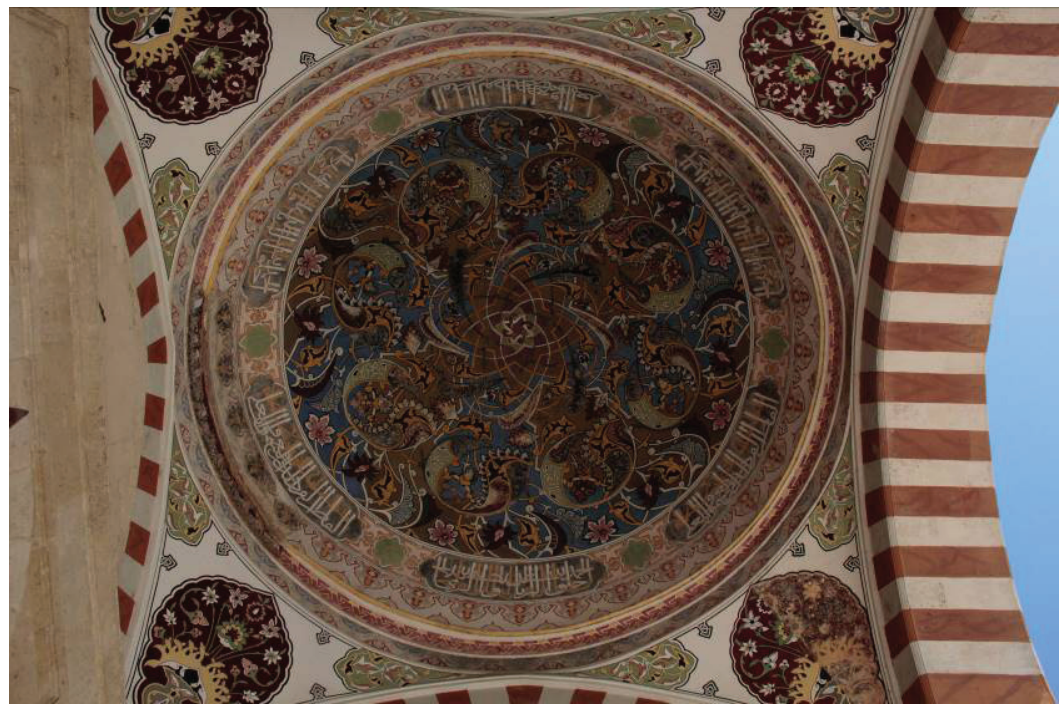

Resim 18. Kubbe No.A.15

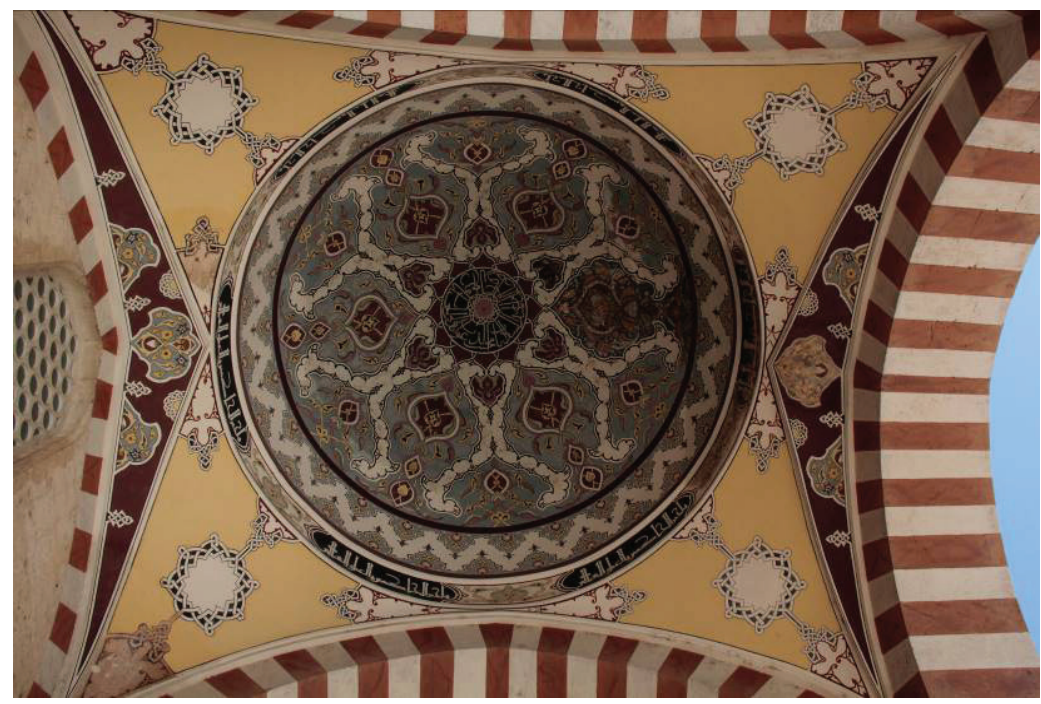

Resim 19. Kubbe No.A.16 


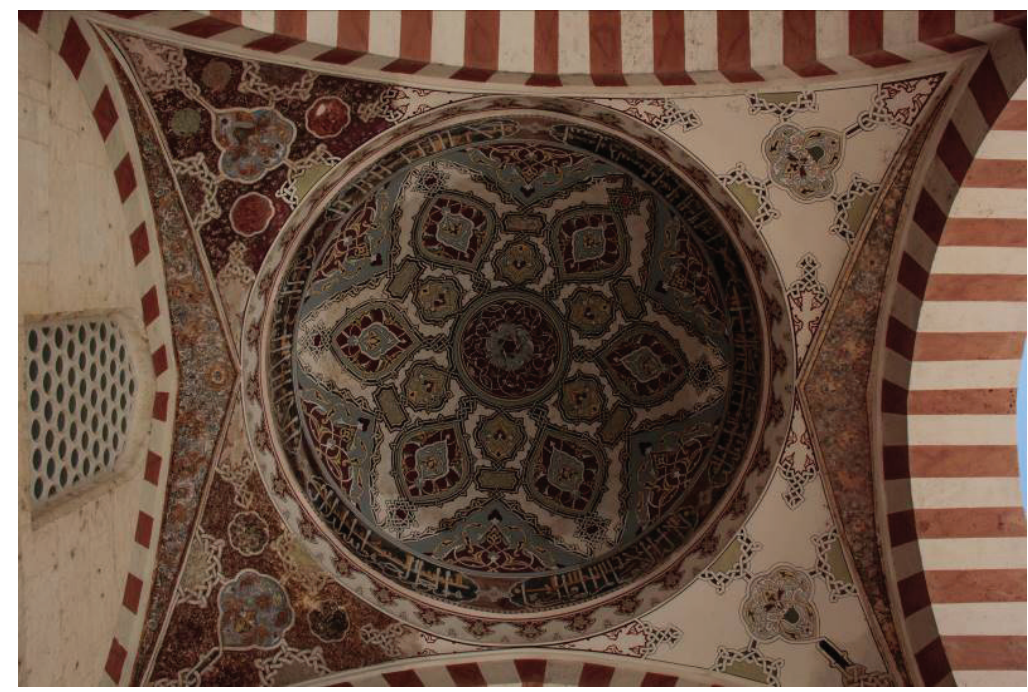

Resim 20. Kubbe No.A.17

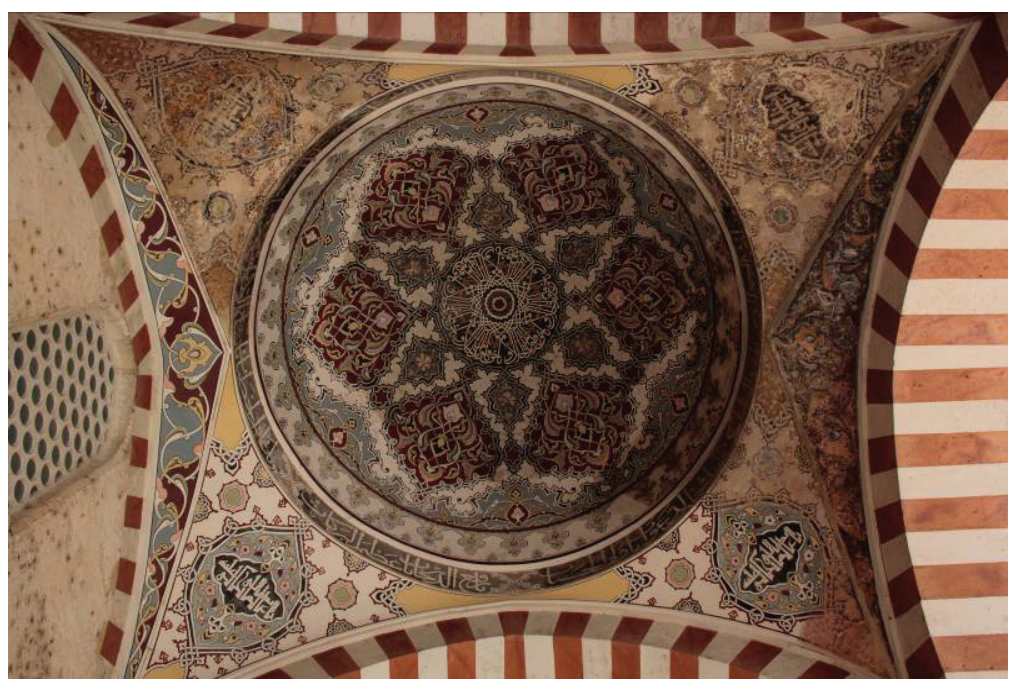

Resim 21. Kubbe No.A.18 


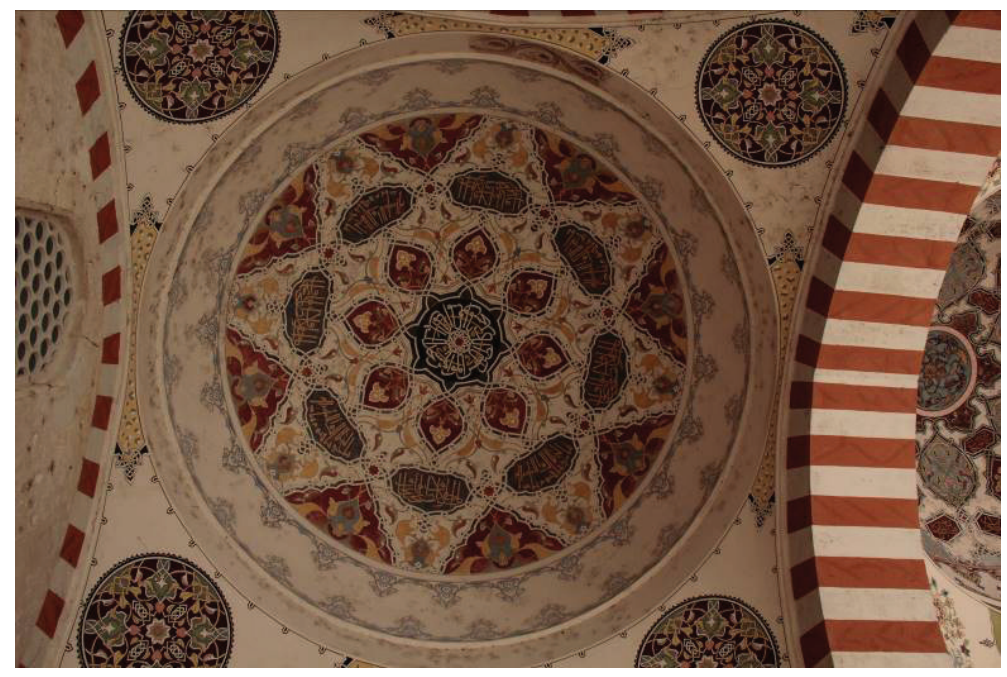

Resim 22. Kubbe No.A.19

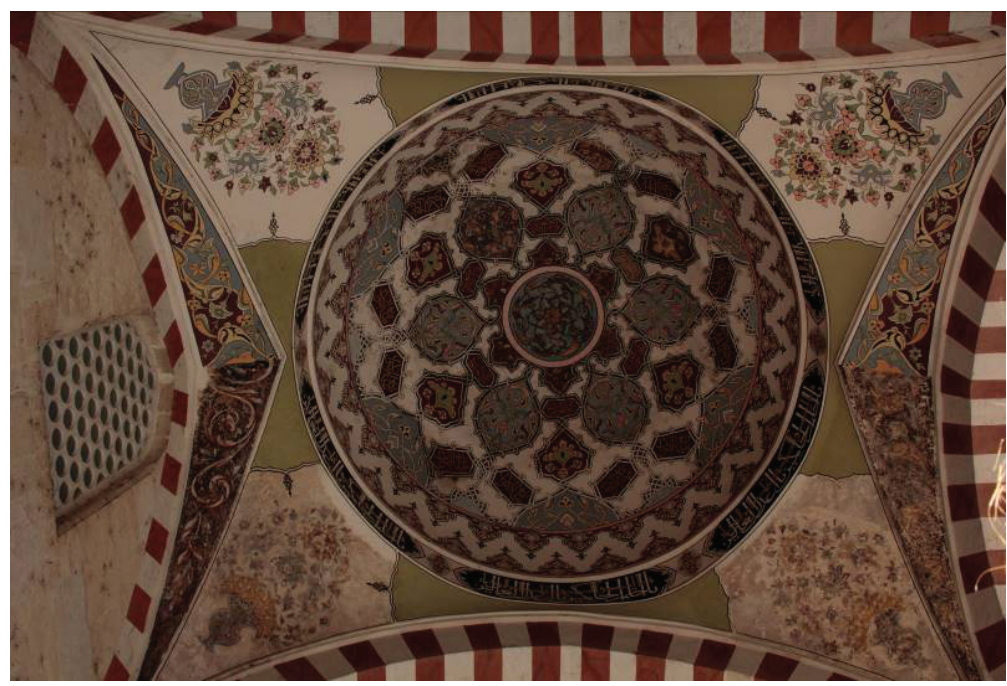

Resim 23. Kubbe No.A.20 


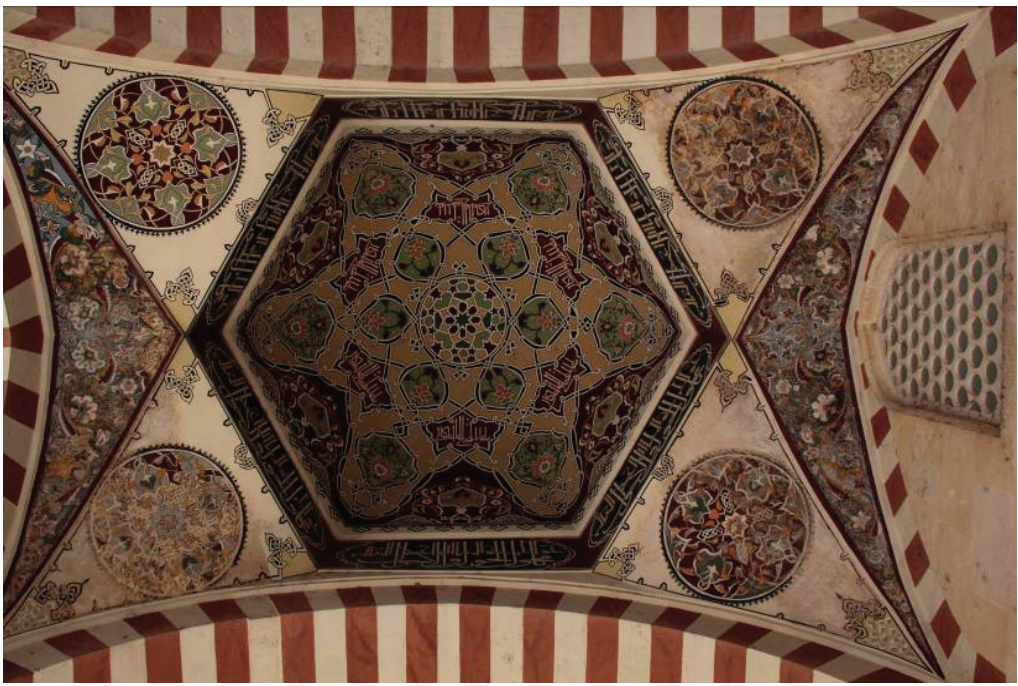

Resim 24. Kubbe No.A.21

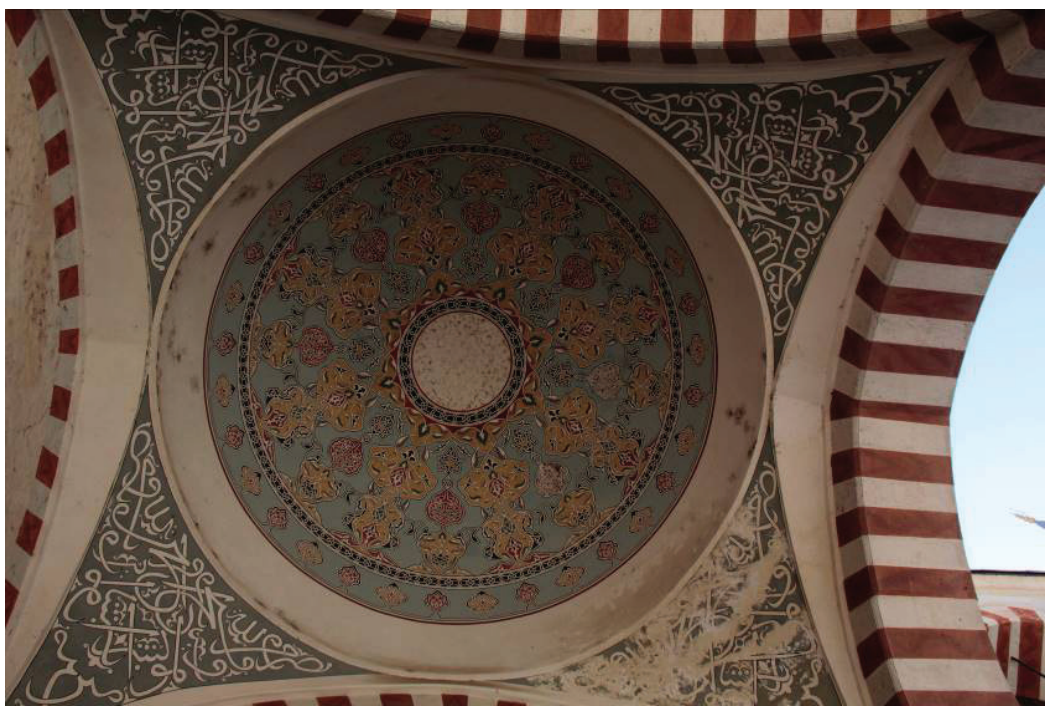

Resim 25. Kubbe No.A.22 


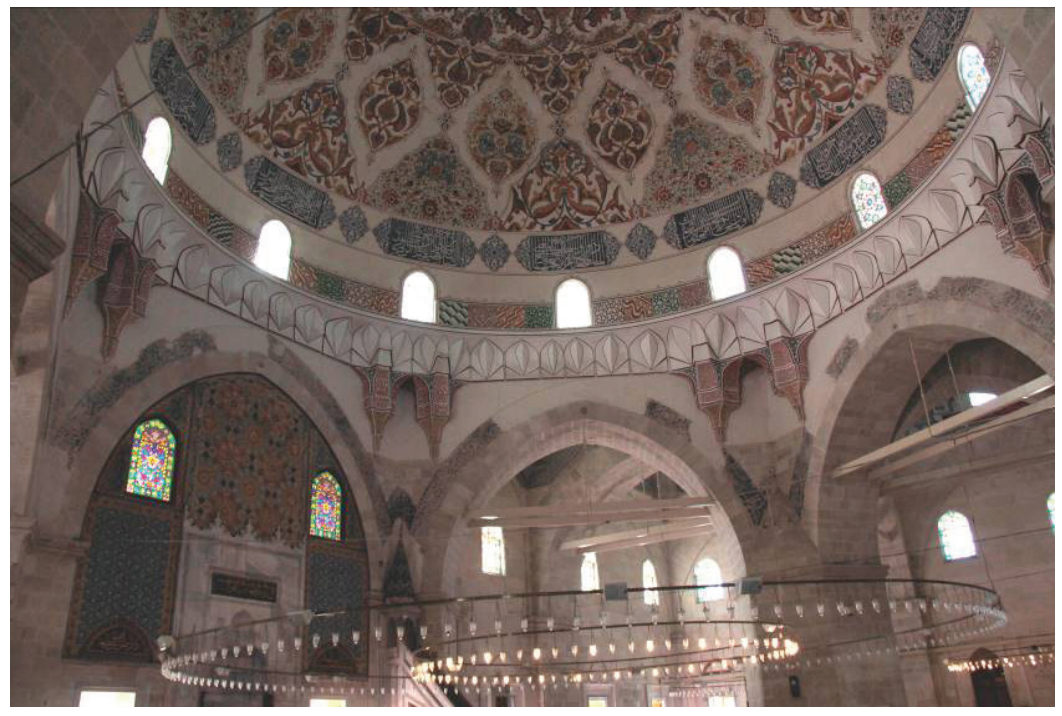

Resim 26. Kubbe No.H.1:(Mihrap önü kubbesi )

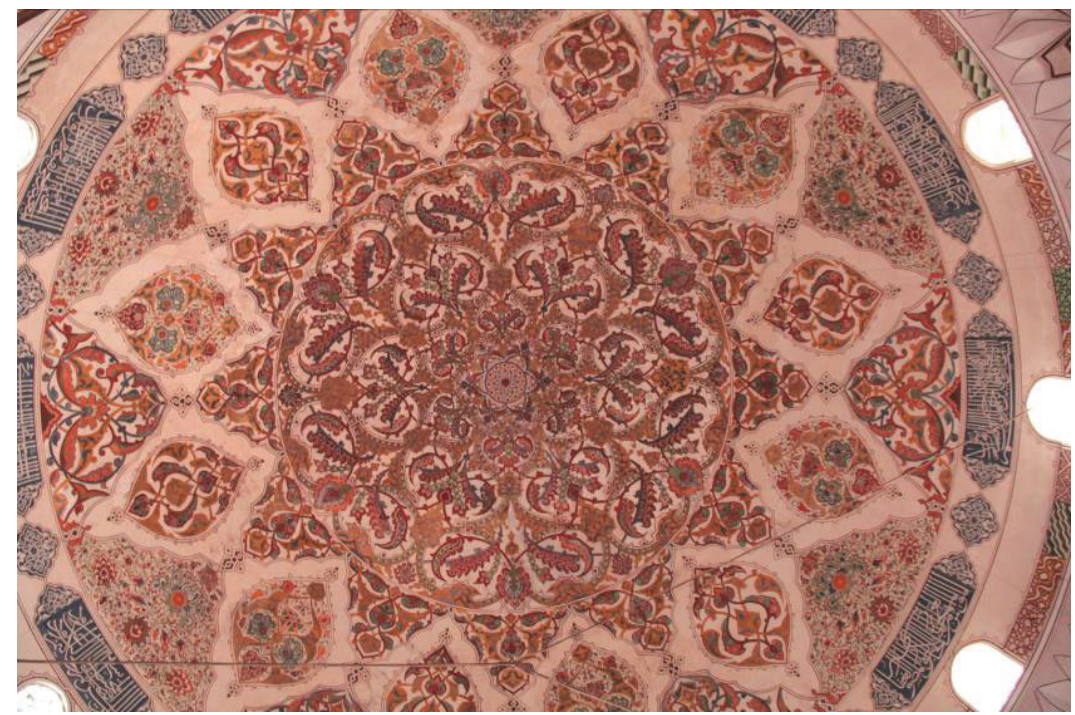

Resim 27. Kubbe No.H.1 


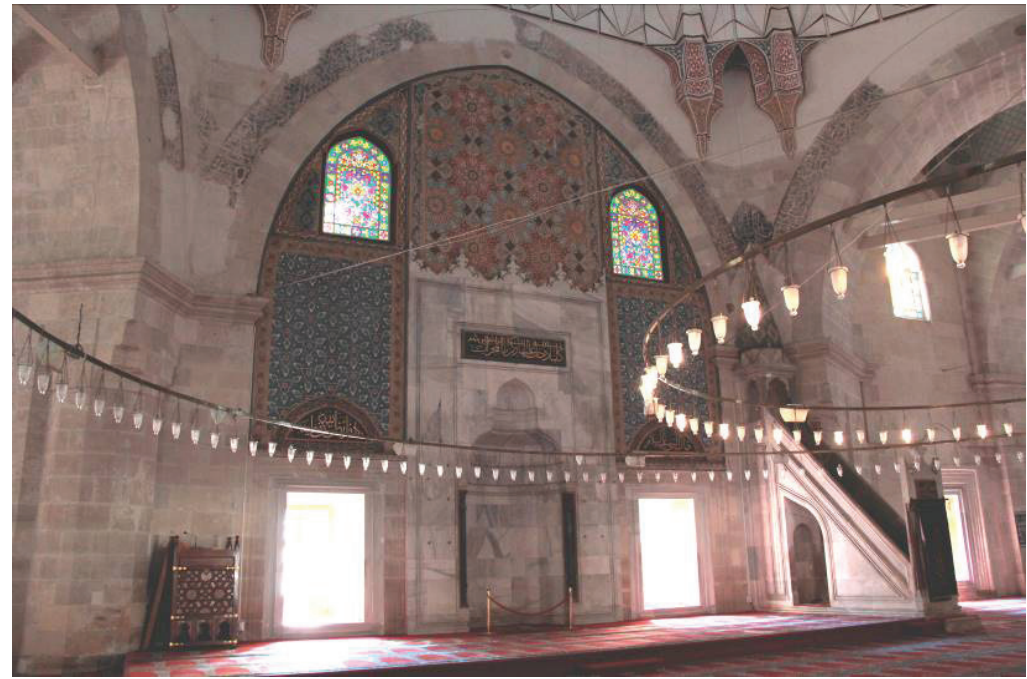

Resim 28. Kubbe No.H.1

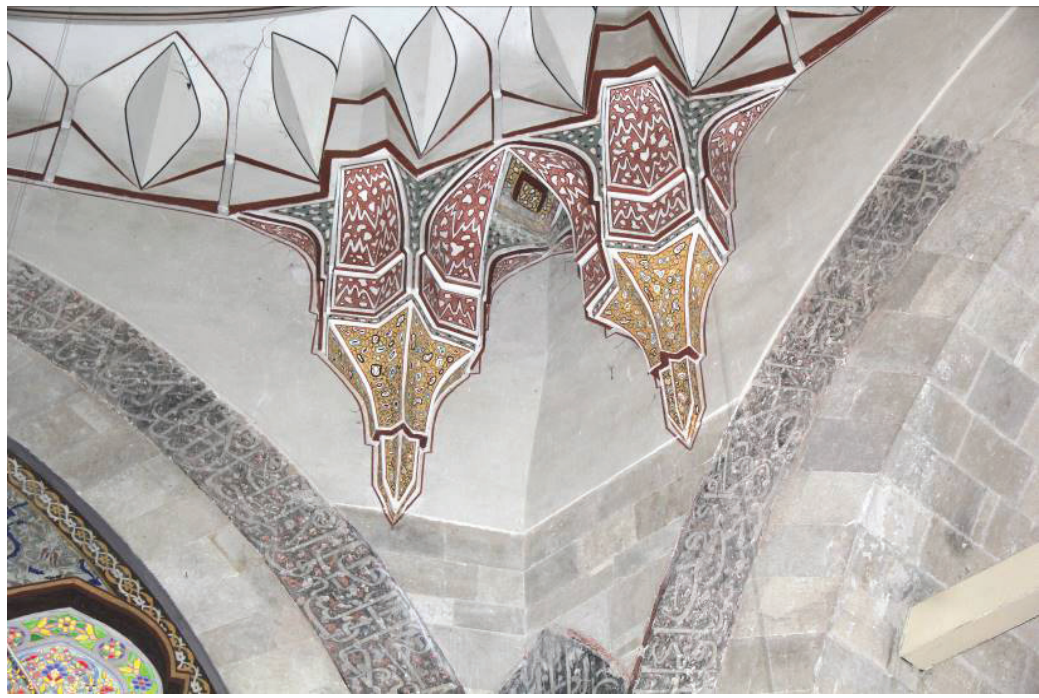

Resim 29. Kubbe No.H.1 


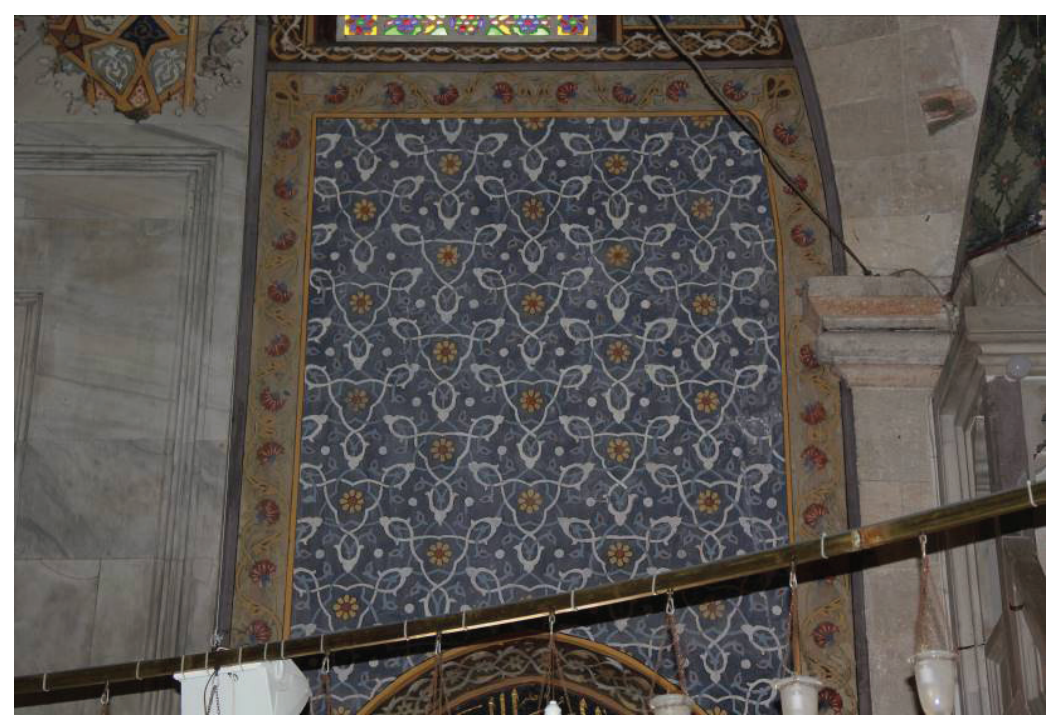

Resim 30. Kubbe No.H.1

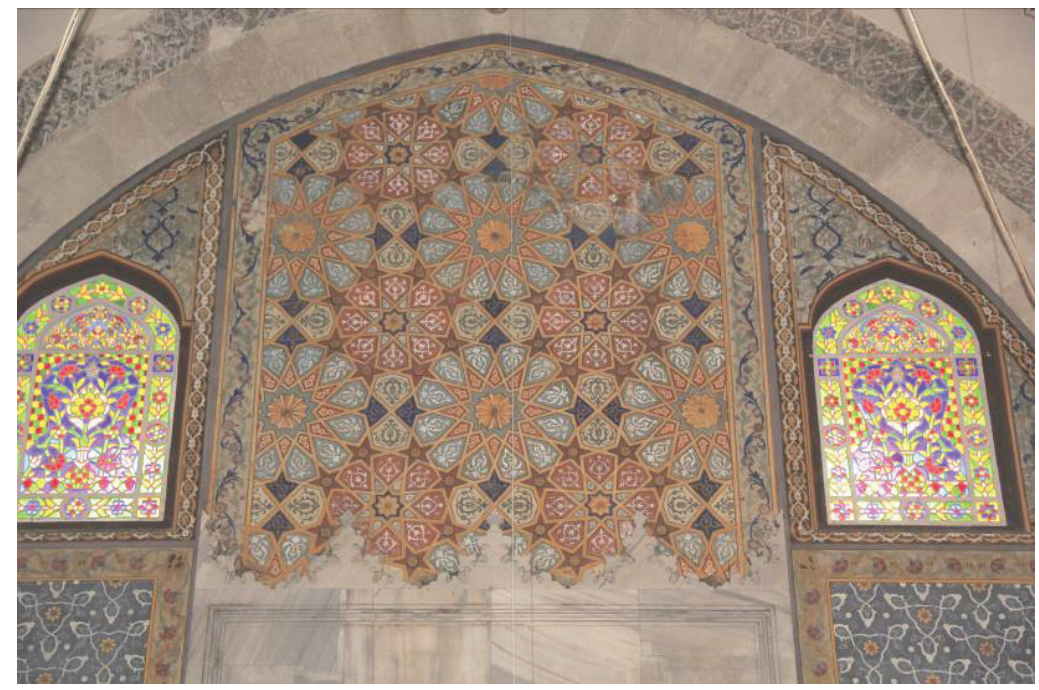

Resim 31. Kubbe No.H.1 


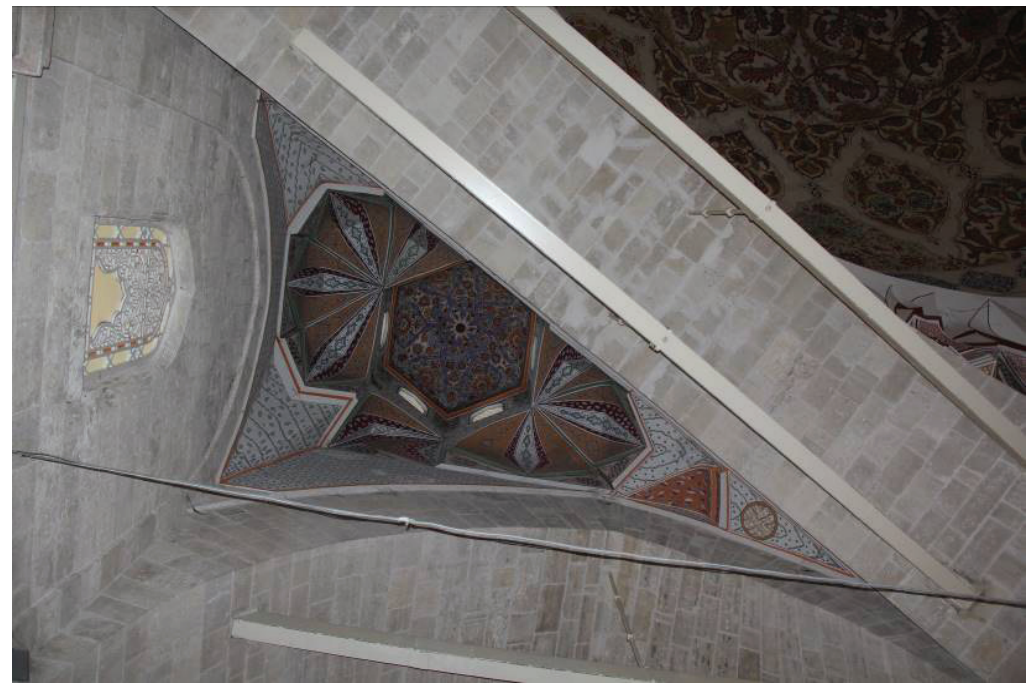

Resim 32. Kubbe No.H.2

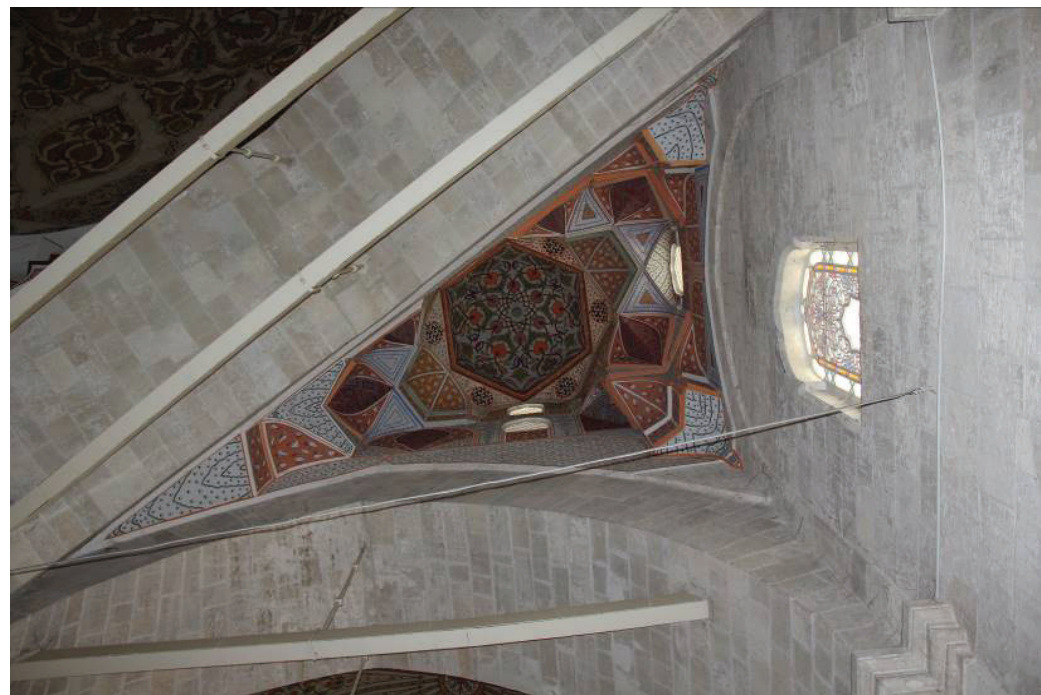

Resim 33. Kubbe No.H.3 


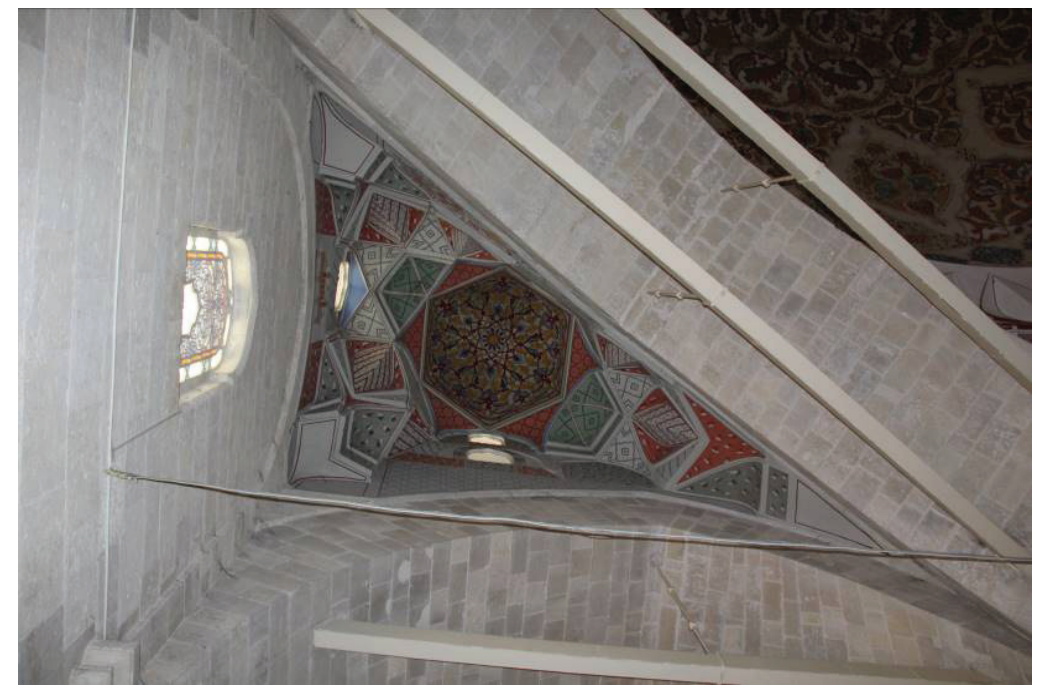

Resim 34. Kubbe No.H.4

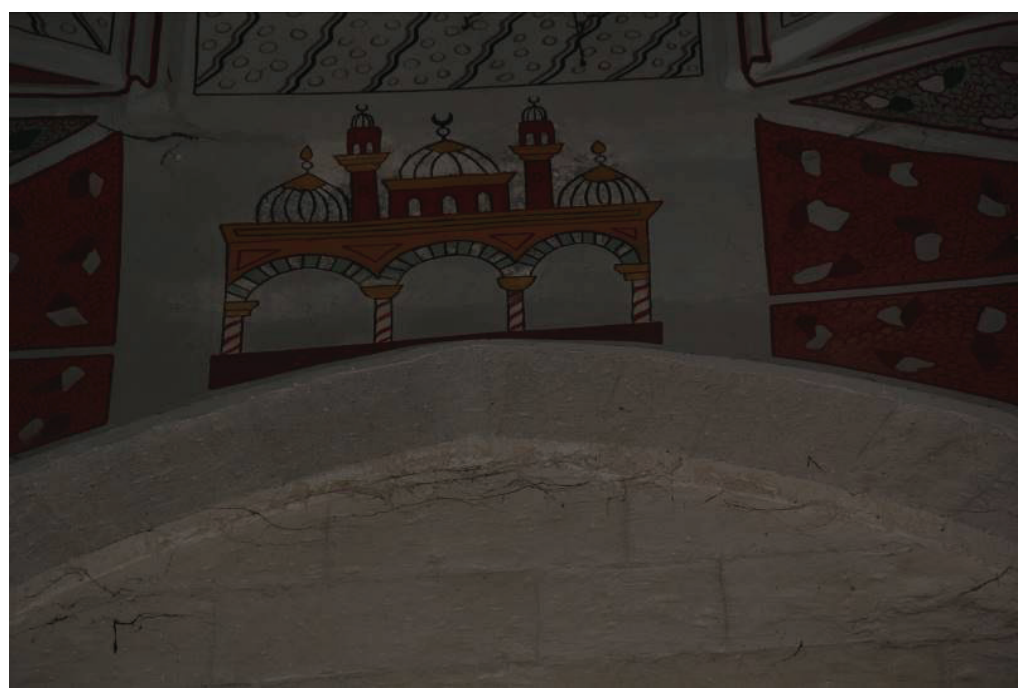

Resim 35. Kubbe No.H.4 


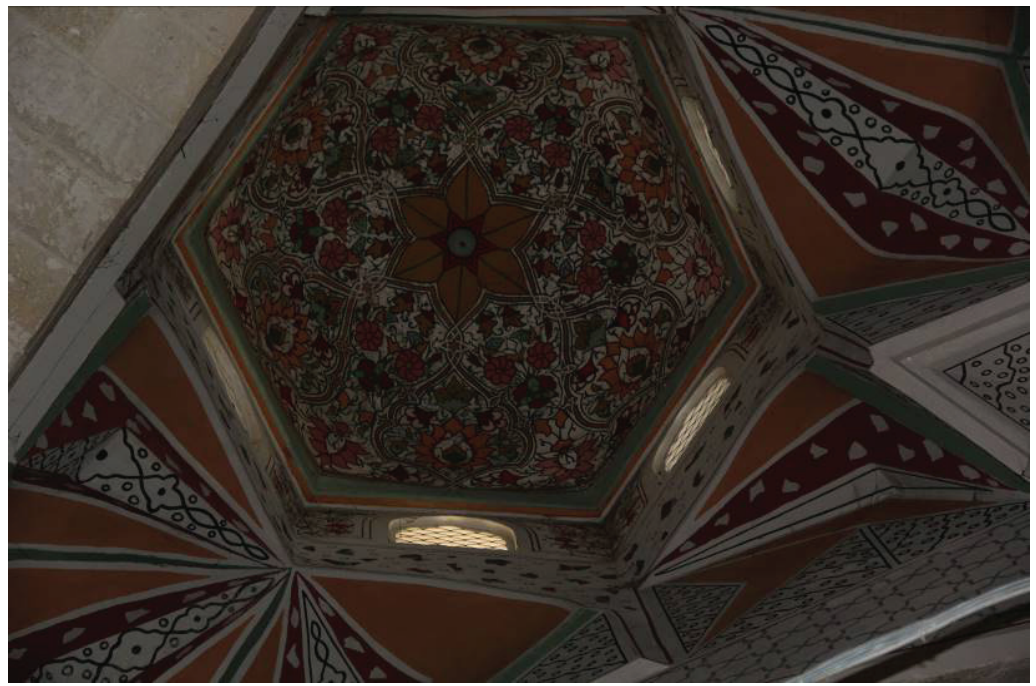

Resim 36. Kubbe No.H.5

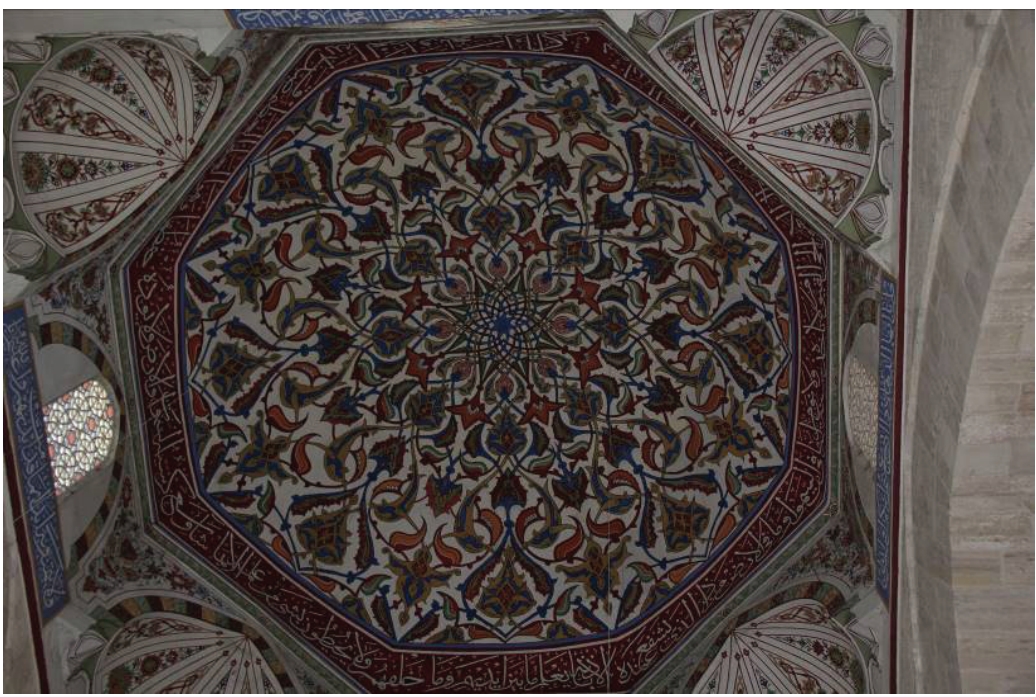

Resim 37. Kubbe No.H.6 


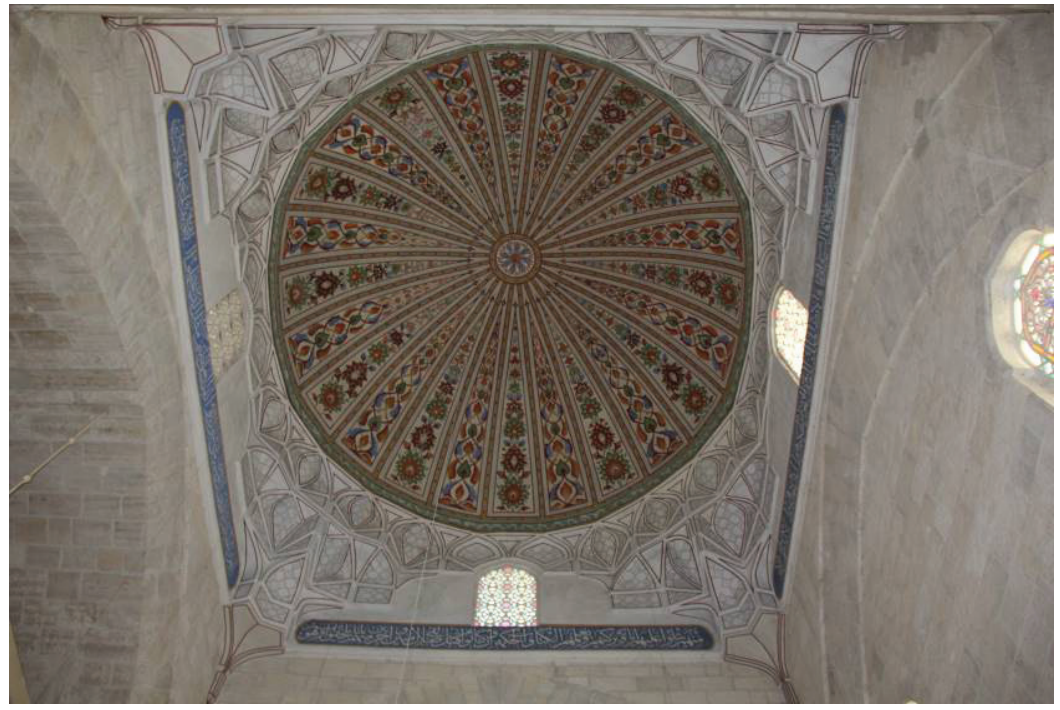

Resim 38. Kubbe No.H.7

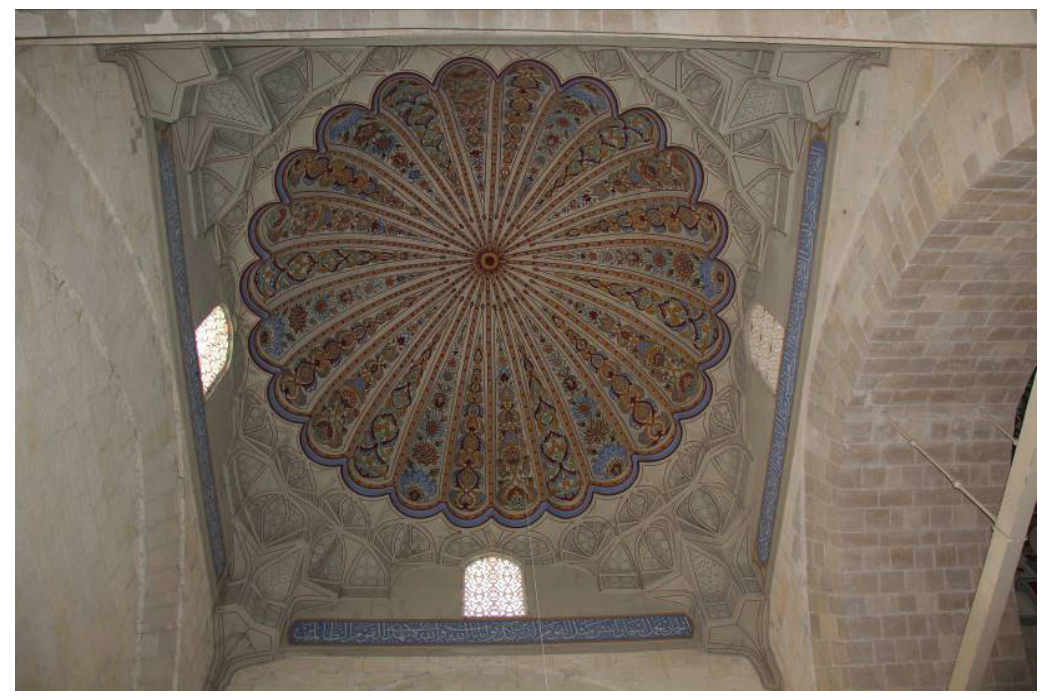

Resim 39. Kubbe No.H.8 


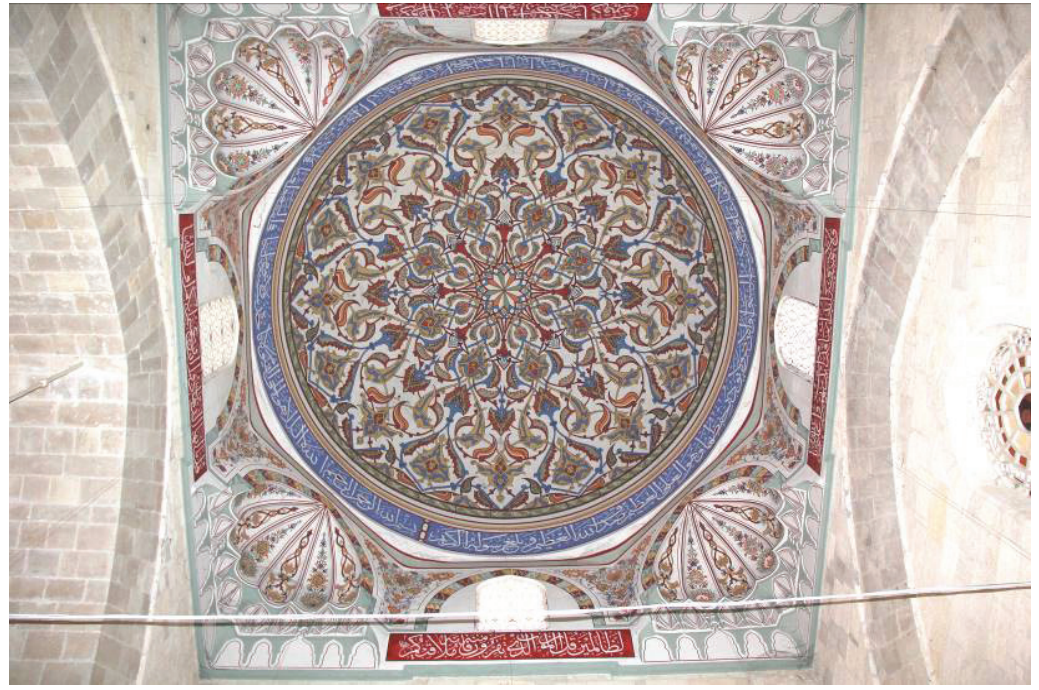

Resim 40. Kubbe No.H.9 